\title{
laborhifórico
}

ISSN 2359-6910

https://revistas.ufrj.br/index.php/lh/

ARTIGO

Recebido em 8 de junho de 2021

Aprovado em 13 de julho de 2021

\section{A redução no quadro de clíticos de terceira pessoa no português brasileiro: um estudo diacrônico}

Reduction of the third person clitic system in Brazilian Portuguese:

a diachronic study

DOI: https://doi.org/10.24206/lh.v7iespec.44191

Maria Eugenia Lammoglia Duarte

Professora Titular do Departamento de Letras Vernáculas da Faculdade de Letras (Universidade Federal do Rio de Janeiro). Atua na área de sintaxe sincrônica e diacrônica do português. Tem interesse em análises contrastivas de variedades do português e outras línguas românicas.

E-mail: eugenia@letras.ufrj.br ORCID: http://orcid.org/0000-0001-8329-1226

Antonio Anderson Marques de Sousa

Doutor em Letras (Língua Portuguesa) pelo Programa de Pós-Graduação em Letras Vernáculas da UFRJ e atua como professor substituto da Faculdade de Letras da mesma instituição e também na rede municipal de ensino.

E-mail: antoniomarques@letras.ufrj.br ORCID: https://orcid.org/0000-0002-6656-0196 


\section{Ulli Santos Bispo Fernandes}

Mestre em Letras Vernáculas (Língua Portuguesa) pelo Programa de PósGraduação em Letras Vernáculas da UFRJ e doutoranda no mesmo programa. Atualmente, trabalha como professora de língua portuguesa do ensino fundamental II no Colégio Recanto. Além disso, tem se dedicado a análises contrastivas da sintaxe da língua portuguesa, particularmente a estudos diacrônicos sobre o sistema pronominal do português brasileiro e do português europeu.

E-mail: ullibispo@yahoo.com.br ORCID: https://orcid.org/0000-0003-0906-2454

\section{Marianna Maroja Confalonieri Cardoso}

Mestre em Língua Portuguesa pelo Programa de Pós-Graduação em Letras Vernáculas da UFRJ e atua como professora do Ensino Médio em instituições da rede pública e privada.

E-mail: mariannamaroja@gmail.com ORCID: https://orcid.org/0000-0002-2432-4849 


\section{RESUMO}

Neste artigo, reunimos três estudos que utilizam as mesmas amostras de peças de teatro brasileiras e portuguesas, escritas ao longo dos séculos XIX e XX, para uma análise de sintaxe comparativa do uso dos clíticos acusativo e dativo para referência à $3^{\text {a }}$ pessoa e do clítico indefinido "se". Com base em propostas sobre seu estatuto, como elementos de concordância, em oposição aos clíticos para referência à $1^{\mathrm{a}} \mathrm{e} 2^{\mathrm{a}}$ pessoas, que se comportam como sintagmas e são dêiticos, encontramos as respostas para seu desaparecimento no português brasileiro e evidências da sua estabilidade e robustez do português europeu. Incluídos entre os elementos de concordância, enfraquecidos no PB tal como os morfemas flexionais verbais, por questões sócio-históricas, esses clíticos passam a ser representados por formas alternativas explicadas, em parte, pela orientação para o discurso e, em parte, para a remarcação do valor do Parâmetros do Sujeito Nulo.

Palavras-chave: Clítico acusativo. Clítico dativo. Clítico indefinido. Português europeu. Português brasileiro.

\section{ABSTRACT}

This article compares the results of three contrastive analyses based on European and Brazilian theatre plays, written across the 19th and the 20th centuries. The comparative work focuses 3rd person accusative and dative clitics and the indefinite clitic "se". Based on theoretical proposals for their status, as agreement elements, as opposed to 1 st and 2nd person clitics, which behave as phrases (NPs) and are deictic, we find evidence for their obsolescence in Brazilian Portuguese (PB) and their strength and high frequency in European Portuguese (EP). Such clitics, just like other inflectional morphemes, weakened for socio-historical reasons in Brazilian Portuguese, have been replaced by alternative forms explained partially by the discourse orientation and partially by the resetting of the value of the Null Subject Parameter in BP.

Keywords: Accusative clitic. Dative clitic. Indefinite clitic. European Portuguese. Brazilian Portuguese. 


\section{Introdução}

Neste artigo reunimos os resultados de três análises diacrônicas do processo de perda de três pronomes clíticos e suas formas substitutivas no português brasileiro (PB), com base em peças brasileiras escritas por autores cariocas ao longo dos séculos XIX e XX, comparando tal percurso com uma amostra de peças portuguesas produzidas em período comparável por autores de Lisboa.

Nossa hipótese principal é a de que a perda desses clíticos é seletiva, atingindo aqueles que não são dêiticos, como são os de $1^{\text {a }}$ e $2^{\text {a }}$ pessoas (me, te), que têm sua interpretação dependente do contexto comunicativo, não podendo, pois, ser omitidos; isso, entretanto, é possível com os clíticos acusativo e dativo com referência à $3^{\text {a }}$ pessoa (o/a - lhe e suas formas plurais), que são anafóricos, sendo identificados por um antecedente fora da sentença em que eles ocorrem, ou ainda com o clítico indefinido (se), que, mesmo sem ter as características dos dêiticos e dos anafóricos, pode ser omitido ou substituído, como mostraremos, por formas pronominais nominativas, dada a sua função se suspender o agente da oração em que ele pode ocorrer.

Não trataremos aqui do clítico reflexivo (me, te, se), cujo comportamento não se compara aos demais. Eles formam um conjunto de comportamento mais uniforme - todos encontram seu antecedente na própria sentença em que ocorrem, ou seja, na função de sujeito (eu me vesti, tu te vestiste, ele se vestiu), e, embora sejam variáveis no PB, essa é uma variação sujeita a fatores diatópicos: algumas regiões têm todo o paradigma de uso frequente, outras apagam o clítico e outras, ainda, elegem o de $3^{\text {a }}$ pessoa para representar todas as três, merecendo estudo à parte. (A esse respeito, recomendamos a leitura de DUARTE; RAMOS, 2015.)

Este artigo se organiza da seguinte forma. Na seção 1, apresentamos uma breve discussão sobre o estatuto dos clíticos aqui analisados; em 2, a metodologia utilizada é apresentada, ilustrando, os três clíticos em análise e suas formas variantes com exemplos de peças brasileiras, já que algumas das estratégias encontradas no PB não são atestadas ou são muito raras no português europeu (PE); listamos os fatores linguísticos e sociais levados em conta (em anexo apresentaremos as duas amostras consolidadas com as peças utilizadas nas três pesquisas, que foram extraídas da mesma grande amostra de que dispomos). Em 3, mostramos os resultados gerais da análise logística a que os dados foram submetidos; essa análise nos fornece a distribuição dos dados e a seleção dos grupos de fatores relevantes para a realização das formas variantes. Em 4 apresentamos, finalmente, as considerações a que os resultados nos permitem chegar. 


\section{Os clíticos de $3^{\mathrm{a}}$ pessoa - seu estatuto no PB e no PE}

Como dissemos na introdução a este artigo, os clíticos de $1^{\mathrm{a}}$ e $2^{\mathrm{a}}$ pessoas (acusativo e dativo) são os que não sofreram alteração no paradigma de clíticos no PB. Trata-se de clíticos dêiticos, que não podem ser excluídos de um enunciado sob pena de comprometer seu entendimento. Uma sentença como " "eu vi $[\varnothing]$ ontem", em que o falante quer dizer "eu (te) vi (você) ontem", seria agramatical, da mesma forma que "ele viu $[\varnothing]$ ontem", significando "ele me viu ontem". Igualmente, uma sentença como "ele deu $[\varnothing]$ um presente", significando "ele me/te deu um presente" não seria corretamente interpretada com o clítico nulo. Por outro lado, essas mesmas sentenças seriam perfeitamente gramaticais se o constituinte apagado tivesse referência anafórica, como ilustramos em (1) e (2):
(1) a. E [o João $]_{\mathrm{i}}$ ?
b. Eu vi $[\varnothing]_{\mathrm{i}}$ ontem. (o João / ele / ?o)
c. A Maria viu $[\varnothing]_{\mathrm{i}}$ ontem. (o João /ele / ?o)
(2) a. E o aniversário d[o João $]_{\mathrm{i}}$ ?
b. Eu acabei dando um belo presente $[\varnothing]_{\mathrm{i} .}$ (pra ele/?lhe)
c. A namorada dele deu um belo presente $[\varnothing]$. (pra ele/? lhe)

Em relação ao clítico indefinido "se" (também referido como "impessoal" por alguns autores), esteja ele numa estrutura tradicionalmente classificada passiva ou ativa, sendo classificado como "se" apassivador ou indeterminador, o fato é que sua presença em uma e outra estrutura suspende o argumento agentivo (sobre o comportamento do "se" no PE e PB, cf. MARTINS; NUNES, 2016). Tal como ocorre com os clíticos acusativo e dativo referidos em (1) e (2) acima, o "se" indefinido já não faz parte do $\mathrm{PB}$ como L1 e sua recuperação parcial pela escola tem mais êxito do que a do acusativo e do dativo, mas o uso dos três clíticos acaba por se limitar à escrita de indivíduos mais letrados ou à fala muito monitorada. Em resumo, o letrado não leva para sua fala espontânea os clíticos que já não aparecem nos dados a que estão expostos no processo de aquisição da linguagem.

O que interessa acerca do "se" não é saber se estamos diante de um "se" passivo ou indeterminador, mas observar que (a) ele pode ter referência "arbitrária" ou "genérica" (uma distinção que devemos a EGERLAND, 2003). Enquanto o sujeito de referência arbitrária pode se referir a um conjunto finito de entidades ou mesmo a um único indivíduo, excluindo o falante, como em (3), caso 
em que o clítico estaria em variação com o verbo na $3^{\text {a }}$ pessoa do plural ou com o pronome nominativo "eles" expresso e ainda com o verbo na $3^{a}$ pessoa do singular sem qualquer marca, um uso apontando por Lunguinho e Medeiros (2009), o de referência genérica abrange um conjunto infinito de entidades, podendo o falante estar ou não incluído, como ilustramos em (4). De todo modo, adiantamos que a ocorrência do clítico já é muito rara, mesmo na fala espontânea de letrados mais velhos. O que se atesta com alta frequência é o uso de "a gente", que já ultrapassa o uso do pronome "nós", o uso de "você" ou "tu", condicionado a questões diatópicas, e, mais uma vez, o uso do verbo na $3^{\text {a }}$ pessoa do singular sem marca, estrutura apontada por Galves (1987). Trata-se de um uso de baixa frequência, se comparado com as formas pronominais nominativas, mas é interessante notar que esse nulo pode ter igualmente referência arbitrária (3d) ou genérica (4d):

(3) a. Criou-se aquele clube em 1920

b. Criaram aquele clube em 1920.

c. Eles criaram aquele clube em 1920.

d. Criou aquele clube em 1920.

(4) a. Não se vê mais amolador de faca.

b. A gente não vê mais amolador de faca.

c. Você/tu não vê mais amolador de faca.

d. Não vê mais amolador de faca.

Para Galves (1993, 2018, 2019), o decréscimo de sujeitos nulos e o aumento de objetos nulos no $\mathrm{PB}$, entre outros fenômenos, deve ser consequência do enfraquecimento da concordância, com a inserção de "você" e sua neutralização com "tu" no paradigma pronominal do PB (sem a marca distintiva de concordância número-pessoal) "como mostram pesquisas sobre a sócio-história das formas de tratamento, bem como os trabalhos sobre o efeito do contato na emergência do PB (..)", mas esta seria "uma explicação parcial, que deve ser inserida num quadro mais amplo de perda de morfologia associada à aquisição do português no Brasil como segunda língua” (GALVES, 2019, p. 129). A autora propõe um modelo em que um morfema de concordância fraco não corresponde a uma categoria funcional Agr, mas a traços abstratos de concordância associados a $T$ (ense), numa categoria complexa T-Agr. Interessa-nos aqui a menção que Galves faz aos pronomes de $1^{\text {a }}$ e $2^{\text {a }}$ 
pessoas que permaneceram no sistema e foram reanalisados como "pronomes plenos" (sintagmas), não sendo mais núcleos que se movem para Agr, o que está em consonância com o que mostramos no início desta seção, sobre o comportamento dos clíticos dêiticos. E, embora a autora só mencione o clítico acusativo de $3^{\text {a }}$ pessoa, podemos estender sua proposta aos três clíticos, objeto deste artigo, excluindo os de $1^{\text {a }}$ e $2^{\text {a }}$ pessoas.

Nunes $(1993,2018,2019)$ se dedica ao clítico acusativo e atribui sua diferença em relação aos clíticos de $1^{\mathrm{a}}$ e $2^{\mathrm{a}}$ pessoas a uma mudança fonológica na direção de cliticização. Sua recuperação se dá quando associado a verbos no infinitivo, contexto que permite a legitimação do onset subespecificado da sílaba complexa do clítico. Como os verbos infinitivos não recebem a marca de concordância do sujeito, há espaço morfológico para o clítico. Quanto à recuperação em contexto de verbo finito, essa é possível pelo fato de o slot sufixal reservado para a concordância já estar ocupado no caso dos verbos finitos. O autor não trata do clítico dativo ou do clítico indefinido, mas sua hipótese é "que houve um enfraquecimento de concordância transcategorial em $\mathrm{PB}$, mais especificamente afetando núcleos de fase: C, v e D" (Nunes, comunicação pessoal). Para o que nos interessa aqui, o autor diz que o enfraquecimento em $\mathrm{C}$ teria resultado na perda do sujeito nulo do $\mathrm{PB}$ e o enfraquecimento em $\mathrm{v}$ teria ocasionado a perda de acusativos e dativos de terceira pessoa.

Tal como o desaparecimento do clítico dativo, o do "se" (genérico e arbitrário) não se deve a questões morfofonológicas, o que ocorreu com o acusativo, mas se consideramos o "se" como ligado ao conjunto de morfemas de concordância fraca, lembrando a proposta de Galves, e levamos em conta a expressiva ocorrência de sujeitos indeterminados representados particularmente por pronomes nominativos expressos (cf. DUARTE, 1995; DUARTE; MARINS, a sair; entre muitos outros), temos evidências suficientes para defender que a perda dos três clíticos está relacionada a uma morfologia fraca, que leva a sujeitos expressos e complementos acusativos e dativos nulos, identificados por um elemento proeminente no contexto discursivo.

No que diz respeito ao PE, temos evidências empíricas de que o paradigma se mantém robusto e seu comportamento conserva, entre outras propriedades, a subida do clítico ("não o tinha visto") e a concordância nas estruturas com "se" passivo.

\section{A Metodologia e o quadro teórico utilizados}

As amostras utilizadas para as três análises são constituídas de peças de teatro de caráter eminentemente popular, escritas por autores brasileiros e portugueses, dedicados ao teatro. Mesmo cientes de que tais textos não reproduzem exatamente a fala, nossa intenção é buscar pistas de uma modalidade próxima da língua oral, partindo do pressuposto de que tais peças foram escritas para 
serem ouvidas pelo público e não deveriam se distanciar muito dele. A maioria das peças é comum às três investigações, mas alguns fenômenos mais raros exigem uma amostra mais ampla.

As peças do $\mathrm{PB}$ foram todas escritas por autores nascidos no Rio de Janeiro e as do PE por autores, em sua maioria, nascidos ou moradores de Lisboa. O Quadro que reúne o conjunto das peças analisadas nas três pesquisas se encontra no Anexo após as referências. A distribuição das peças em sete períodos - dois situados no século XIX e cinco no século XX - se deve, em primeiro lugar, ao fato de que o número de autores dedicados apenas ao teatro popular no Brasil do século XIX não é muito expressivo, o que não ocorre ao longo do século XX. Essa distribuição irregular, contudo, pelo que tem sido mostrado nos inúmeros trabalhos que utilizam essa amostra, não nos deixa dúvida de que o século XIX e as duas primeiras décadas do século XX revelam a gramática do português europeu, o que, sem dúvida, deve ser creditado ao modelo que inspirou as primeiras gramáticas normativas no passado e ainda inspira no presente, com raríssimas exceções.

Todas as análises utilizam o quadro da Teoria da Variação e Mudança Linguística (WEINREICH; LABOV; HERZOG, 1968) e, naturalmente, as descrições gramaticais recentes advindas da teoria de Princípios e Parâmetros (BIBERAUER et al., 2010, as propostas descritas na Introdução e outras que serão apresentadas na seção seguinte); além disso, são revisitados estudos empíricos sobre os temas. Tudo isso constitui o componente gramatical indispensável para guiar o estabelecimento de hipótese e o levantamento dos grupos de fatores linguísticos para cada análise, buscando respostas para as questões que a Teoria da Variação e Mudança nos coloca. Como fatores não linguísticos, são levados em conta o autor da peça, que pode nos revelar diferenças individuais, e o período de tempo em que ela se encaixa para responder à questão da transição, no caso de atestarmos mudança em curso. A coleta e codificação dos dados segue a metodologia variacionista e utiliza a ferramenta Goldvarb X (SANKOFF; TAGLIAMONTE; SMITH, 2005) para a distribuição dos dados e a análise estatística.

$\mathrm{Na}$ seção seguinte mostramos os três clíticos em análise - o clítico acusativo, o dativo e o indefinido - e suas variantes atestadas na amostra de peças do PB.

\section{Os clíticos em extinção e suas formas substitutivas}

\section{$2.1 \mathrm{O}$ clítico acusativo e suas variantes}

Marques de Sousa (2017) considerou em sua análise as seguintes variantes, representadas pelo clítico acusativo, pelo pronome nominativo, por um SD anafórico e pelo objeto nulo: 
(5) a. - [Os mineirinhos $]_{\mathrm{i}}$ entrarão aqui e hão de levar por força alguma coisa esse é o seu costume. O que é preciso é enganá-[los $]_{\mathrm{i}}$.

(PB - O noviço, Martins Pena, 1845)

b. - Enquanto eu fui comprar cigarros, $[\text { Rosa }]_{i}$ subiu pelo elevador e o elevador enguiçou com [ela $]_{\mathrm{i}}$ lá dentro. Você quer ver se o Nanico tira $[\mathrm{ela}]_{\mathrm{i}}$ de lá?

(PB - Um elefante no caos, Millôr Fernandes, 1955)

c. - Enquanto aqui estiverem hospedados [os americanos $]_{\mathrm{i}}$ ninguém quer ser criado desta pensão. A cidade inteira está farta de saber que não se pode aturar [essa gente $]_{\mathrm{i}}$

(PB - O simpático Jeremias, Gastão Tojeiro, 1918)

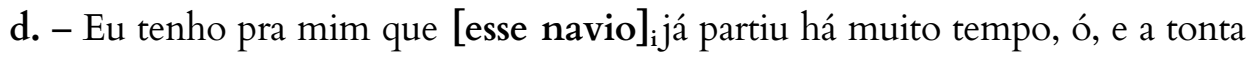
da Margareth tá esperando $[\varnothing]_{\mathrm{i}}$ no cais.

(PB - No coração do Brasil, Miguel Falabella, 1992)

O uso do termo "acusativo anafórico" usado por Marques de Sousa, em vez de objeto direto anafórico, se deve à inclusão de dados em que o elemento que recebe caso acusativo é um sujeito de orações completivas infinitivas de verbos causativos, de permissão e de percepção, além dos sujeitos de miniorações. Tais sujeitos no PB costumam aparecer com a forma nominativa - daí o termo "ele acusativo". Além dos acusativos anafóricos que retomam um SD, como em (5) acima, Marques de Sousa (2017) também analisa os objetos que retomam uma proposição, uma vez que esse representa o contexto mais favorável à implementação do objeto nulo no português. Como mostra Cyrino (1994, 1997), em sua análise diacrônica, o português sempre exibiu elipses proposicionais (oracionais) em variação com o clítico neutro "o", ou o demonstrativo neutro "isso".

(6) a. - [Vossa Excelência está subpedânea no conceito público $]_{\text {i }}$ - Eu assim $[0]_{i}$ entendo.

(As doutoras, França Júnior, 1889)

b. - [Querem que tu sejas freira para não te darem dote quando te casares $]_{\mathrm{i}}$. - Quem te disse [isso] $]_{\mathrm{i}}$ ?

(PB - O Noviço, Martins Pena, 1845)

Neste artigo excluímos o objeto proposicional e os SDs anafóricos, supostamente uma estratégia de esquiva ao clítico ou ao "ele" acusativo. Entretanto, trata-se de uma estratégia pouco produtiva na fala espontânea (DUARTE, 1986) e nas peças de teatro. Além disso, como mostra (5c), nem sempre a retomada é feita com o mesmo $\mathrm{SD}$, trazendo, em geral, nuances semânticas e tampouco é produtiva 
nesse gênero, tal como na fala espontânea (DUARTE, 1986). A dissertação de Marques de Sousa trata os objetos proposicionais à parte, além de nos oferecer duas análises com antecedentes não oracionais: uma incluindo os SDs anafóricos e outra sem eles. Neste artigo, não incluímos os objetos proposicionais.

Os grupos analisados levam em conta fatores de natureza morfológica, sintática e semântica, a partir de trabalhos empíricos clássicos e propostas teóricas recentes para o licenciamento do objeto nulo, entre os quais Duarte e Costa (2013) e Cyrino e Matos (2016).

\subsection{O clítico dativo e suas variantes}

Fernandes (2018) levantou as seguintes formas de realização do dativo argumental: o clítico "lhe", o SP encabeçado pelas preposições “a” ou "para (pra)" e o dativo nulo:

(7) a. - A respeito de [teu filho $]_{\mathrm{i}}$ direi o mesmo. Tem [ele $]_{\mathrm{i}}$ nove anos e será prudente criarmo-lo desde já para frade.

- Já ontem comprei-[lhe $]_{\mathrm{i}}$ o hábito com que andará vestido daqui em diante.

(PB - O noviço, Martins Pena, 1845)

b. - Quando você enfrenta [um espelho $]_{\mathrm{i}}$, o que é que você pergunta [a ele $]_{\mathrm{i}}$ ? (PB - A mulher integral, Carlos Eduardo Novaes, 1975)

c. - É isso mesmo, Cristina, [seu marido] $]_{i}$ gosta de ser servido por você, não pela sua empregada. Faz uma salada $[\text { pra ele }]_{\mathrm{i}}$

(PB - A mulher integral, Carlos Eduardo Novaes, 1975)

d. - Se for [seu filho] $]_{\mathrm{i}}$, abra a porta naturalmente e não diga nada $\varnothing_{\mathrm{i}}$.

(PB - Um elefante no caos, Millor Fernandes, 1955)

Os grupos de fatores considerados na análise foram a transitividade verbal, o tipo de preposição utilizada na realização da variante com SP. A autora partiu de estudos sobre a ausência do clítico dativo para referência à $3^{\mathrm{a}}$ pessoa no $\mathrm{PB}$ oral, nas variedades culta e popular, na implementação da preposição "para" (reduzida para (pra) a partir dos estudos de Gomes (2003, 2011), que analisou, respectivamente, a amostra PEUL e uma amostra da escrita jornalística, e Freire (2000), que fez uma comparação das variedades lusitana e brasileira na modalidade oral, atestando a alta produtividade do dativo na primeira. Utilizou também a análise de Freire (2005), que compara a modalidade escrita nas duas variedades, seguindo um contínuo, que começa com textos menos formais até os mais formais. Freire revela que o clítico é a estratégia preferida no PE, independentemente do grau de formalidade 
do texto escrito, enquanto no $\mathrm{PB}$, é recuperado via letramento e chega a alcançar índices em torno de $30 \%$ nos gêneros mais formais, como ensaios e editoriais.

\section{$2.3 \mathrm{O}$ clítico indefinido e outras formas de indeterminação do agente}

A análise de Cardoso (2017) sobre as estratégias de indeterminação contou com a colaboração de Vargas (2010, 2012), que disponibilizou seu corpus com dados das peças do PB, analisado em sua dissertação de mestrado. Cardoso reanalisou os dados à luz de desdobramentos mais recentes no tratamento da indeterminação, como mostramos a seguir.

Nas descrições tradicionais, como sabemos, o clítico indefinido "se" juntamente com o uso da $3^{\mathrm{a}}$ pessoa do plural, com o pronome nulo, constituem as duas únicas maneiras de veicular a indeterminação do agente. Esses compêndios se inspiram nos moldes lusitanos, e, a bem da verdade, utilizam a língua literária de outras sincronias, o que justifica a descrição que lá se encontra. Uma menção às GTs não pode esquecer que seu propósito nunca foi lidar com a língua oral e muito menos falar em mudança linguística; por isso, não podem ser criticadas. Este não é o caso de pesquisas linguísticas, que, longe de reproduzir a tradição, trazem uma descrição da fala e da escrita efetivamente praticadas pelos membros de uma comunidade de fala ou de uma variedade linguística. Isso é o que mostram inúmeras pesquisas, entre as quais Cavalcante (1999), Duarte (1995), Marins, Soares da Silva e Duarte (2015, 2017, entre outros), que apontam, ao lado de formas conservadoras, então não consideradas como de indeterminação, formas inovadoras, que foram surgindo ao longo do tempo, ampliando as possibilidades de veicular a indeterminação, particularmente no PB. E, embora todas as variantes atestadas digam respeito a um sujeito cuja referência não está definida no contexto discursivo, elas não abrangem um conjunto de indivíduos idênticos, como comentamos acima, e, portanto, não constituem, em seu conjunto, formas em variação.

Nesse sentido, a linguística moderna iniciou uma distinção entre elas, segundo sua referência "arbitrária" ou "genérica", como mencionamos. Cardoso (2017) faz uma distribuição das estratégias variantes seguindo um "contínuo" de indeterminação, proposto por Marins, Soares da Silva e Duarte (2015, 2017), que distribuem as estratégias de indeterminação, efetivamente em variação, em três pontos de um gradiente.

Os exemplos em (8), num dos extremos do contínuo, ilustram as estratégias de referência "arbitrária”, que, segundo Marins, Soares da Silva e Duarte são representadas pelo feixe de traços $\left[+3^{a}\right.$ pessoa/+pl], podendo se realizar pelo clítico "se", (8a), pelo pronome (eles), nulo ou expresso, (8b), ou ainda por um nulo arbitrário, com o verbo na $3^{\text {a }}$ pessoa do singular $(8 c)$, sem qualquer marca, não atestado na amostra de peças. É particularmente interessante observar que o sujeito poderia ser 
realizado por um clítico "se" arbitrário, como no PE, pelo pronome (eles) + verbo no plural, ou mesmo por uma passiva analítica:

(8) a. Já em Nicéia $\varnothing_{\text {arb }}$ reuniu-se um concílio para decidir se a mulher devia ou não fazer parte do gênero humano.

(PB - As doutoras, França Júnior, 1889)

b. Imagine a senhora que $\varnothing_{\text {arb }}$ confundiram o Adalberto, meu cunhado, com terrorista procuradíssimo.

(PB - Como encher um biquíni selvagem, Miguel Falabella, 1992)

c. $\varnothing_{\text {arb }}$ Construiu um posto na esquina da minha rua. (= Construiu-se um posto na esquina da minha rua / Construíram um posto na esquina da minha rua / Foi construído um posto na esquina da minha rua / Um posto de gasolina foi construído na esquina da minha rua)

Os dois grupos seguintes se referem aos sujeitos de referência genérica, abrangendo um conjunto infinito de entidades. Num deles, estão os sujeitos que incluem necessariamente o falante, representados pelo feixe de traços $\left[+1^{\text {a }}\right.$ pessoa $\left./+\mathrm{pl}\right]$ :

(9) a. As coisas são como são e não como nós queremos que elas sejam.

(PB - O simpático Jeremias, Gastão Tojeiro, 1918)

b. É essa a minha intenção. Mas nem tudo que a gente deseja pode ser alcançado.

(PB - O hóspede do quarto n², Armando Gonzaga, 1937)

Finalmente, no outro extremo do gradiente, temos aquelas estratégias genéricas que se caracterizam pelos traços [+3 a pessoa/-plural], incluindo as que podem ou não incluir o falante, representadas pelo "se" genérico, pelos pronomes nominativos "você/tu" e pelo nulo genérico, que apresenta um verbo na $3^{\text {a }}$ pessoa do singular (repetimos que tanto o "se" quanto o nulo $+3^{\mathrm{a}}$ ps. podem veicular a referência arbitrária ou genérica):

(10) a. É verdade, nunca $\varnothing_{\text {gen }}$ se soube do paradeiro dele.

(PB - O colar de coral, Antonio Callado, 1954)

b. No Rio você coloca uma meia sola em 15 minutos. Em Salvador o sapateiro manda você apanhar o sapato no dia seguinte.

(PB - Confidências de um espermatozoide careca, Carlos Eduardo Novaes, 1984) 
c. $\varnothing_{\text {gen }}$ Tem que aprender a mexer com aqueles ferrinhos, mas o salário parece que compensa. (você/a gente tem que aprender....)

(PB - No coração do Brasil, Miguel Falabella, 1992)

Enquanto o nulo arbitrário em (8c) exclui o falante, o que se encontra em (10c), com duas ocorrências nas peças recentes e de uso também baixo na fala espontânea (DUARTE, 1995), veicula valor modal ou aspectual e o sujeito nulo poderia ser substituído qualquer uma das formas ilustradas em (9) ou em (10a,b).

Para a análise das formas de indeterminação, foram elencados os seguintes grupos de fatores: as variantes usadas para cada ponto do contínuo, a forma dos pronomes nominativos (nulo ou pleno), a transitividade verbal, a concordância vs não concordância entre verbo e argumento interno no plural nas construções com o clítico "se" + verbo transitivo direto.

\section{Os resultados}

\subsection{Clítico acusativo e suas variantes em PE e PB}

Foram levantados 450 dados para o $\mathrm{PE}$ e 625 para o $\mathrm{PB}$, considerando as quatro variantes que retomam um antecedente não oracional. Entretanto, decidimos para este artigo, apresentar a segunda análise de Marques de Sousa, sem os SDs anafóricos, seja por limitação de espaço seja pelo fato de que esta não é uma estratégia frequente na fala espontânea e nem no texto das peças. Além disso, a retomada do antecedente pode trazer um item novo com alteração semântica, como vemos em (11):

(11) a. Enquanto aqui estiverem hospedados [os americanos $]_{i}$ ninguém quer ser criado desta pensão. A cidade inteira está farta de saber que não se pode aturar [essa gente] $]_{\mathrm{i}}$

(PB - O simpático Jeremias, Gastão Tojeiro, 1918)

b. Então temos aqui [um bastardo $]_{\mathrm{i}}$ ? E ela vai mandar [o rapazola $]_{\mathrm{i}}$ para a grande cidade, a Casa dos Bons do Rossetti?

(PE - Um filho, Luísa Costa Gomes, 1996)

Ficamos, assim, com 408 dados para o PE e 490 para o PB. Como esperado, não foi encontrado um dado sequer da variante "ele" acusativo nas peças portuguesas; ao mesmo tempo, como mostram os resultados, descritos mais adiante, a variante é igualmente raríssima nas peças brasileiras. 
O Gráfico 1 mostra a distribuição das duas atestadas no PE ao longo do tempo.

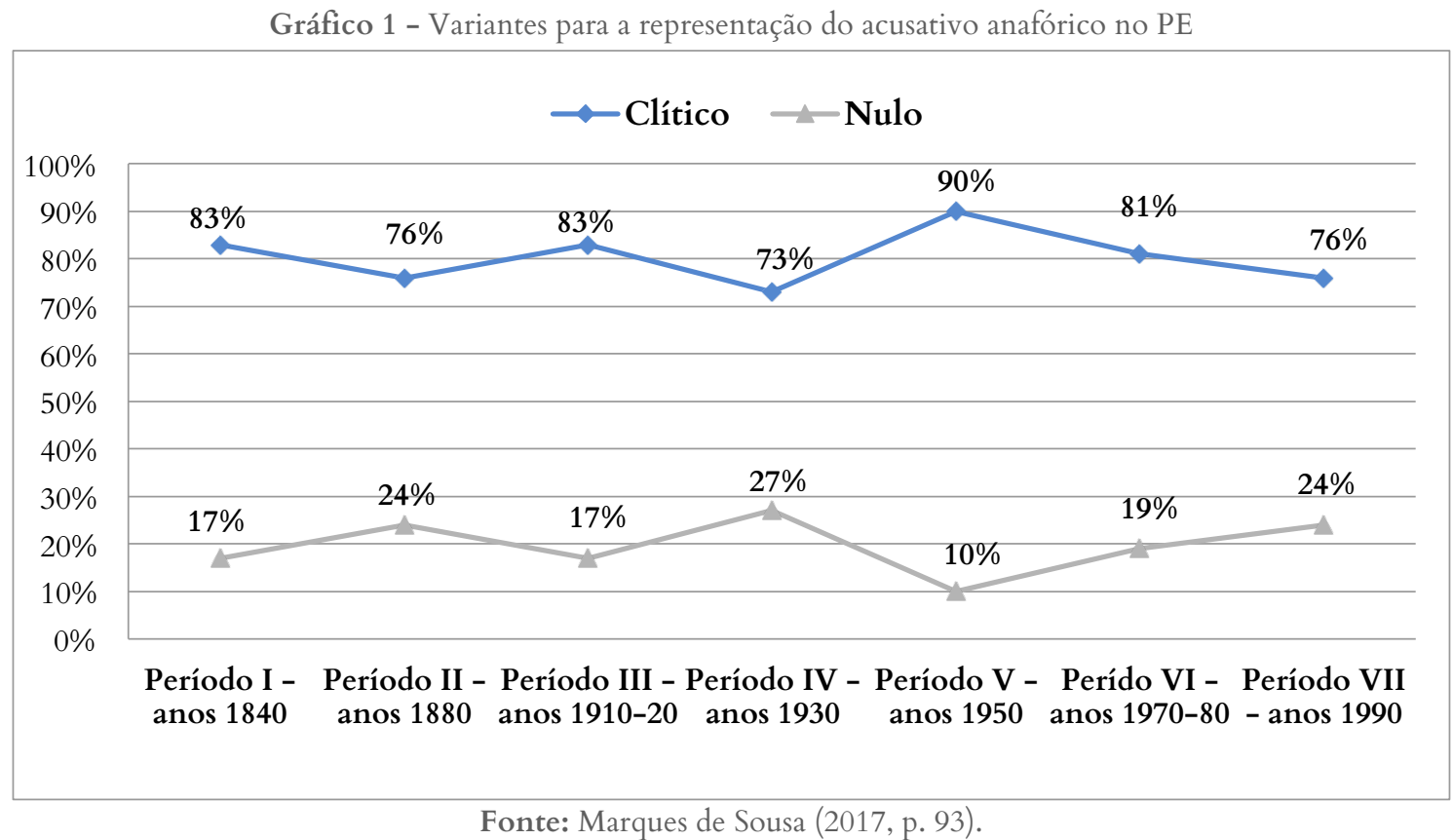

Fica evidente a regularidade e a robustez do clítico acusativo no PE, enquanto o objeto nulo é marginal, aqui ilustrados em (12):

(12) a. O Marrafa e o Janeiro saíram também em busca [do patrão] $]_{\text {i. }}$ É bem possível que já $[0]_{\mathrm{i}}$ tenham encontrado.

(PE - O rosto levantado, Noberto Ávila, 1977)

b. [Os pianos Sakamura $]_{\mathrm{i}}$ já vão amestrados. O cliente compra $[\varnothing]_{\mathrm{i}}$, chega a casa e o piano toca.

(PE - Um filho, Luísa Costa Gomes, 1996)

Por outro lado, a distribuição das variantes para o PB no Gráfico 2 nos revela um quadro bastante diferente: 
Gráfico 2 - Variantes para a representação do acusativo anafórico no PB, com antecedente não oracional

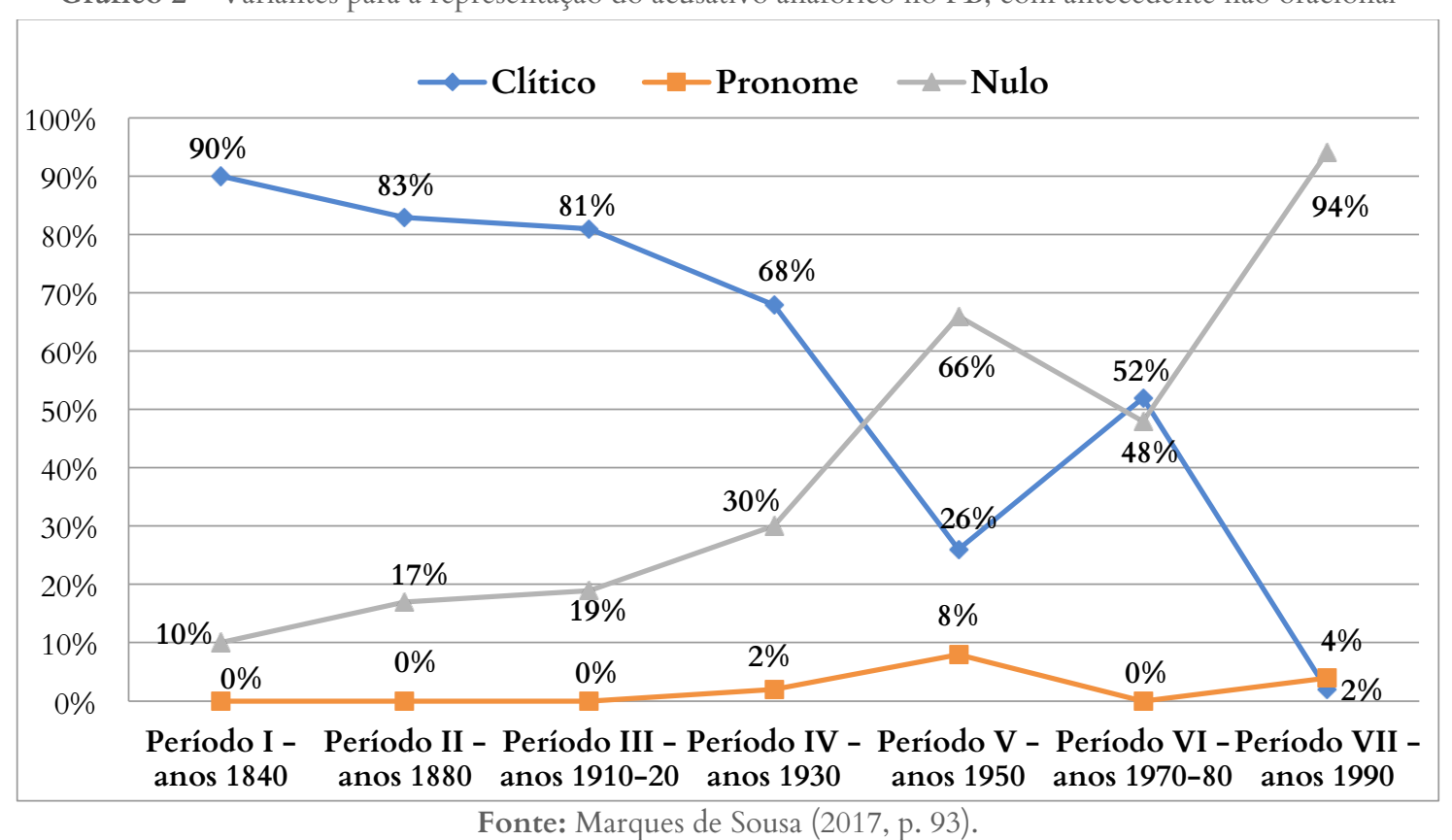

Quando mapeamos, especificamente, a trajetória do clítico acusativo no PE e no PB, os resultados mostram percursos opostos nas variedades em questão: em primeiro lugar, é possível verificar que, mais especificamente nos três primeiros períodos, PE e PB exibem o mesmo comportamento em relação ao clítico acusativo, numa clara demonstração de que a gramática das peças brasileiras é a lusitana. A partir dos anos 1930 vemos uma curva descendente no $\mathrm{PB}$, que chega a $68 \%$ no quarto período, desce para $26 \%$ nos anos 1950, sobe nos anos 1970, para cair drasticamente, chegando a 4\% na última sincronia (anos 1990). No sentido inverso, vemos o objeto nulo no PB, partindo de $10 \%$ e seguindo sua curva ascendente, com um pequeno acidente no período VI (anos 1970, quando praticamente empata com o clítico), para chegar aos anos 1990 com 94\%, um resultado, que está absolutamente em consonância com o que se atesta na fala espontânea. Vejamos mais alguns exemplos do PB:

(13) a. Assim que $[\mathrm{ele}]_{\mathrm{i}}$ sair, não $[\mathrm{lhe}]_{\mathrm{i}}$ dêem tempo de fugir; lancem-se de improviso sobre $[\mathrm{ele}]_{\mathrm{i}}$ e levem-[no $]_{\mathrm{i}}$ à força.

(PB - O Noviço, Martins Pena, 1845)

b. - Que nada, minha folha. [Ele] foi me buscar em Caçapava. Tamos juntos de novo!

$-\mathrm{E}$ tu aceitou $[\mathrm{ele}]_{\mathrm{i}}$ de volta?

(PB - No coração do Brasil, Miguel Falabella, 1992) 
c. Eu tenho pra mim que [esse navio] $]_{\mathrm{j}}$ já partiu há muito tempo, ó, e a tonta da Margareth tá esperando $[\varnothing]_{\mathrm{i}}$ no cais.

(PB - No coração do Brasil, Miguel Falabella, 1992)

Quanto ao uso ele acusativo, o Gráfico revela que a variante é atestada pela primeira vez, nas peças, no Período IV (anos 1930), no Período V (anos 1950) e no Período VII (anos 1990). Como a estratégia é muito rara na amostra, decidimos mostrar todas as ocorrências em (14), chamando a atenção para o fato de que os raros dados confirmam a preferência por antecedentes com o traço [+humano], com apenas dois exemplos com o traço [-humano], (14e, h). Um dos dados exibe um caso de ele acusativo funcionando como sujeito de oração infinitiva, complemento do verbo de permissão "deixar" (14d), um uso corrente no PB oral e já implementado na escrita. Tais ocorrências mostram bem os contextos que favorecem o uso do pronome nominativo em função acusativa, além de confirmarem o fato de que, na fala espontânea, apesar de tão criticado pela escola, seu uso fica muitíssimo abaixo da estratégia que viria a se tornar a mais forte variante para expressar o acusativo anafórico no PB: o objeto nulo. Vejamos as ocorrências de "ele" acusativo na amostra do PB:

(14) a. - Que pilhéria é essa $\mathrm{d}[\mathrm{o} \text { Candinho }]_{\mathrm{i}}$ aqui em casa?

- Olhe [ele $]_{i}$ aí.

(O Hóspede do quarto no 2, Aramando Gonzaga, 1937)

b. - Ah, mãe, você está enganada a respeito d[esta moça $]_{\text {i. }}$

- Você já conhecia [ela $]_{i}$ ?

(Um elefante no caos, Millôr Fernandes, 1955)

c. Enquanto eu fui comprar cigarros, $[\text { Rosa }]_{i}$ subiu pelo elevador e o elevador enguiçou com $[\mathrm{ela}]_{\mathrm{i}}$ lá dentro. Você quer ver se o Nanico tira $[\mathrm{ela}]_{\mathrm{i}}$ de lá?

(Um elefante no caos, Millôr Fernandes, 1955)

d. Paulo, estão atirando n[o homem que saiu daqui $]_{\mathrm{i} .}$ É melhor fechar a porta! Não deixa [ele $]_{i}$ entrar!

(Um elefante no caos, Millôr Fernandes, 1955)

e. Devolvo [teus brincos] $]_{\mathrm{i}}$ como prova da sinceridade do meu amor. Você esqueceu $[\mathrm{eles}]_{\mathrm{i}}$ comigo.

(Um elefante no caos, Millôr Fernandes, 1955) 
f. - E [o pai $]_{\mathrm{i}}$ ? $[\varnothing]_{\mathrm{i}}$ Te dá alguma coisa?

- Só desgosto! Eu bem que fui no quartel, pra ver se o comandante enquadrava $[\text { ele }]_{i}$, mas não deu em nada.

(No coração do Brasil, Miguel Falabella, 1992)

g. - Que nada, minha filha. [Ele $]_{i}$ foi me buscar em Caçapava. Tamos juntos de novo!

- E tu aceitou $[\text { ele }]_{i}$ de volta?

(No coração do Brasil, Miguel Falabella, 1992)

h. [Uma aranha enorme $]_{\mathrm{i}}$ me atacou. Quebrei a vassoura esmagando [ela $]_{\mathrm{i}}$.

(No coração do Brasil, Miguel Falabella, 1992)

Não surpreende, pois, que a análise de regra variável não tenha selecionado o período de tempo para a realização do objeto no PE, dada a estabilidade das variantes, e que tenha colocado este mesmo grupo de fatores em primeiro lugar na seleção para o PB. Não há mudança no PE, mas sim no PB ao longo do tempo. Um grupo de fatores selecionado apenas para o PE diz respeito à função do antecedente, um grupo refinado por Marques de Sousa, que leva em conta o antecedente fora do período em que o acusativo em análise ocorre (um tópico discursivo) ou um antecedente dentro do período em que o acusativo em análise ocorre, esteja em função de sujeito ou de complemento. Aqui está a importância de um antecedente como tópico discursivo (fora do período em que ocorre o antecedente) para a ocorrência de um objeto nulo no PE. No PB, as restrições são muito menores, já que a expansão do objeto nulo rompe todos os condicionamentos.

\subsection{O clítico dativo e suas variantes}

Foram levantados 274 dados para o $\mathrm{PE}$ e 371 para o $\mathrm{PB}$, distribuídos em três variantes: (i) clítico dativo, (ii) SP anafórico e (iii) dativo nulo. Os Gráficos a seguir mostram o percurso das três variantes ao longo do tempo para o $\mathrm{PE}$ e o $\mathrm{PB}$, respectivamente: 
Gráfico 3 - Ocorrência do clítico dativo e suas variantes no PE ao longo do tempo

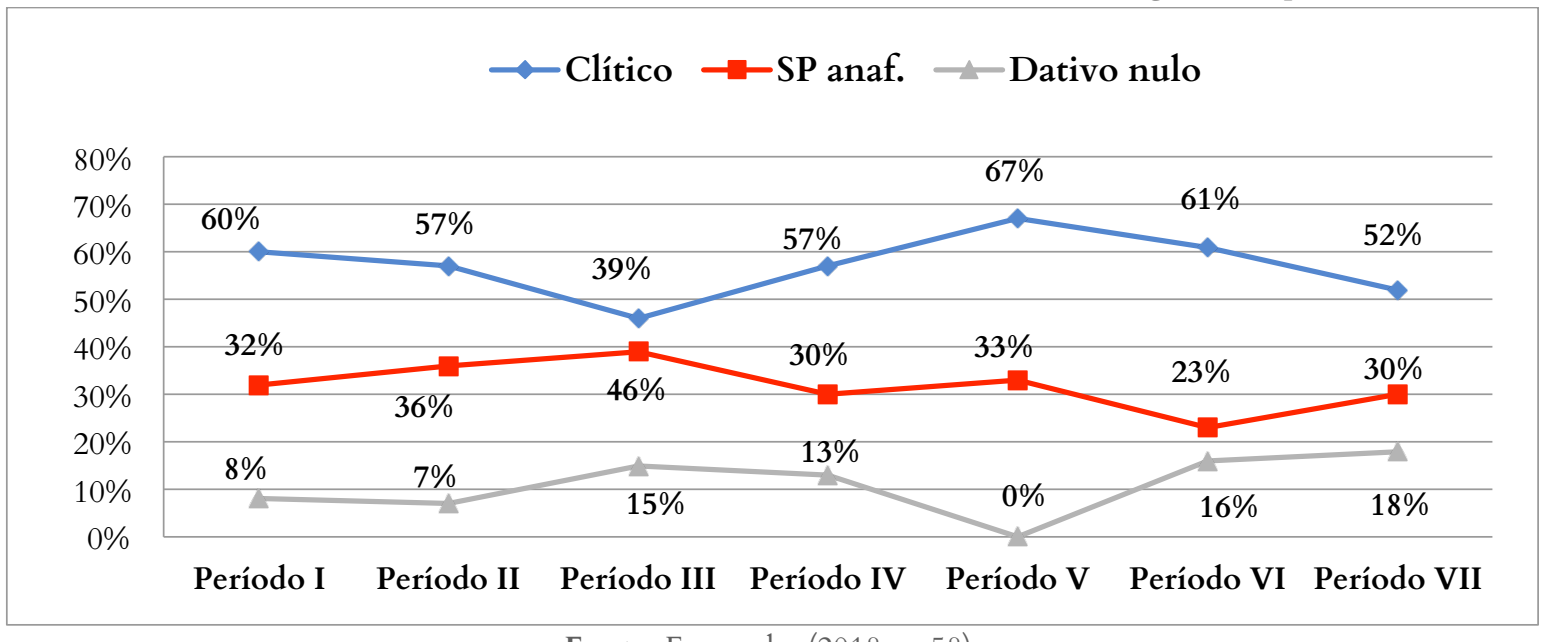

Fonte: Fernandes (2018, p. 58).

A realização do clítico dativo no PE é estável ao longo do tempo, sempre superando o uso do SP anafórico, que se mostra também estável, em torno de 30\% em média. O dativo nulo é sempre a estratégia menos frequente, oscilando entre 7\% e 18\%. Só no período V, a estratégia não é atestada. Alguns exemplos da amostra aparecem em (15):

(15) a. - Pobres mulheres: quanto soffremos ás mãos dos [nossos tyrannos! $]_{\mathrm{i}}$... A culpa porém não é delles, é nossa. Com mel nos labios e fel no coração, accreditamos seus embustes; e ai de nós, que desapercebidas, lhes $_{\mathrm{i}}$ entregamos o repouso da nossa existencia!...

(PE - Os logros numa hospedaria, Paulo Midosi, 1841)

b. - Sabe que está a chegar [o Pantaleão de Sá Repolho] , Morgado das Barrocas, e promettido esposo de sua filha?

- Sei sim, e até [para elle $]_{\mathrm{i}}$ mandei apromptar esses dois quartos, que dão sobre o cáes.

$$
\text { (PE - Os logros numa hospedaria, Paulo Midosi1841) }
$$

c. - Para mim foi a primeira vez. E para [ele $]_{i}$, olha que não sei. Tinha um facies que não enganava muito. E então eu disse $[\varnothing]_{i}: " b e m$, apanhou-me. Mas agora vamos considerar o problema de outro ponto de vista", e ele disse: "Pois, o meu ponto de vista. Tome lá a multa.“

(PE - Um filho, Luísa Costa Gomes,1996)

Vejamos os resultados para o PB: 
Gráfico 4 - Ocorrência do clítico dativo e suas variantes no PB ao longo do tempo

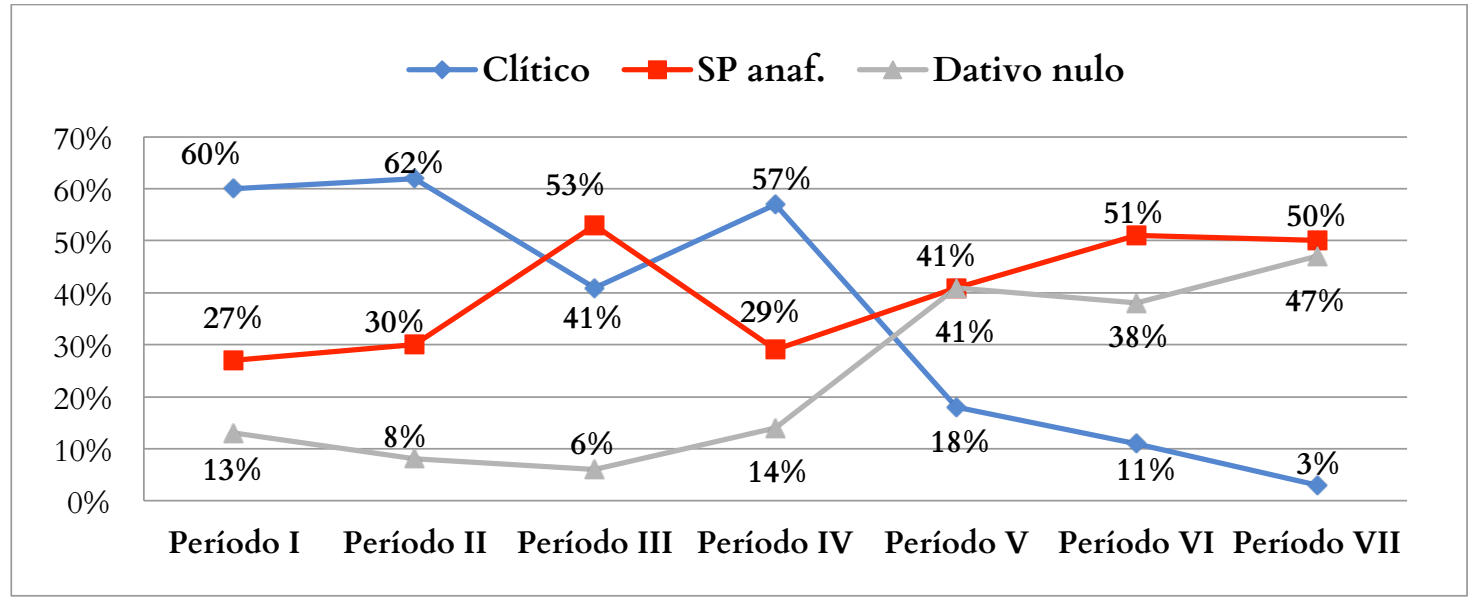

Fonte: Fernandes (2018, p. 61).

O gráfico revela que o uso do clítico dativo começa como a estratégia preferida, até o período IV, com um leve declínio no período III, um aumento no período IV, para iniciar uma curva descendente brusca a partir de então, chegando a 18\% no período V (anos 1950/1960), e, finalmente, a apenas 3\%, correspondente a um único dado, na última sincronia (anos 1990), mostrando um percurso semelhante ao do clítico acusativo no PB. Esse resultado confirma o que é atestado para a língua oral, com a completa obsolescência do clítico dativo para referência à $3^{\text {a }}$ pessoa. O SP anafórico revela curva ascendente, partindo de $21 \%$ na primeira sincronia para se estabilizar em torno de $50 \%$, numa variação estável; curva igualmente ascendente, apesar de mais lenta, é a atestada para o dativo nulo, que geralmente ocorre com os verbos dandi, dicendi e rogandi, quando praticamente empatada, nos anos 1990, com o SP anafórico. Vejamos três exemplos do PB em (16):

(16) a. - Pois saberá. Asseguro-lhe que Dona Nair vai ficar contentíssima e, está claro, lucrarei com isso.

- Vai lhe dar outro sabiá?

(PB - Onde canta o sabiá, Gastão Tojeiro, 1920)

b. - Nada substitui [a mulher de carne $]_{\mathrm{i}}$ e osso e é [a ela $]_{\mathrm{i}}$ que quero dedicar minha estreia no palco.

(PB - Confidências de um espermatozóide careca, C. Eduardo Novas, 1984)

c. - $[\text { Ela }]_{\mathrm{i}}$ me amou como se eu fosse o último homem sobre a Terra. Ou o primeiro. E só depois eu perguntei $[\varnothing]_{\mathrm{i}}$ quem era. E ela me disse.

(PB - Um elefante no caos, Millôr Fernandes, 1955)

No que diz respeito ao uso das preposições "a” e "para”, nos SPs anafóricos, destacamos que, no PE, a preposição "a", ilustrada em (16b) acima, apresentou percentual de realização altíssimo em todas 
as sincronias observadas e foi, de longe, a estratégia preferida para introduzir os SPs anafóricos de $3^{\text {a }}$ pessoa, representando a quase totalidade dos usos. O comportamento do $\mathrm{PB}$, por sua vez, no que se refere ao uso da preposição, mudou ao longo do tempo. Até o período $\mathrm{V}$, que equivale aos anos 1950/1960, o uso da preposição "a” representava mais de 80\%; a partir do período VI, porém, é possível observar mudanças: a preposição "para" revela aumento expressivo, chegando a 44\% no período VI e 72\% no período VII (anos 1990), aproximando-se do PB oral:

(17) a. - Sempre estou muito cansada! É que esta ladeira antes da sua casa custa a subir. E então [o José da Maria Rosa] ${ }_{i}$ não me sai ali em baixo ao encontro.

- Mas afinal a Sr. ${ }^{a}$ Luísa Maria sustenta a sua palavra ou quer dar a água [ao José da Maria Rosa] $]_{\mathrm{i}}$ ? A sua vinda a esta casa parece indicar novidade (PE - A liberdade eleitoral, Teixeira de Vasconcelos, 1870)

b. Não tem nada contra enquanto não é a mulher $d[e l e]_{i}$. Se $[\text { ele }]_{i}$ vê você vestida de coelhinha certamente vai identificá-la com essas mulheres cuja moral, no fundo, [ele $]_{i}$ condena. Você disse [a ele $]_{i}$ que era uma coelhinha da Playboy? (PB - A mulher integral, Carlos Eduardo Novaes, 1975)

(18) a. - Menos de um ano, para fazer face a certas despesas, fui obrigado a fazer um empréstimo a um dos meus sócios, [o Menezes] $]_{\mathrm{i}}$. Contava poder reembolsá-lo dentro do prazo combinado [...].

- oh, Rui! E então?

- E então...quer dizer que se não pagar [...] a minha posição na empresa transfere-se automaticamente [para o Menezes] .

(PE - Alguém terá que morrer, Luís Fancisco Rebello, 1954)

b. [Essa mulher $]_{\mathrm{i}}$ é um monstro! E eu pagando uma fortuna [pra ela $]_{\mathrm{i}}$.

(PB - Como encher um biquini selvagem, Miguel Falabella, 1994)

\subsection{O clítico indefinido e suas variantes}

Foram levantados 1194 para o $\mathrm{PE}$ e 958 dados para o $\mathrm{PB}$, reunindo as estratégias com "se" indefinido, que veiculam a referência arbitrária e genérica. Comecemos a análise pelos sujeitos de referência arbitrária, distribuídos nas tabelas 1 e 2. (Como o nulo com o verbo na $3^{\text {a }}$ pessoa do singular não ocorreu com a referência arbitrária e houve apenas dois casos para veicular a referência genérica, esses dados são excluídos das tabelas do PB. Não há ocorrências no PE desse tipo de estrutura.) 
(19) a. Então, meu amigo, $\varnothing_{\text {arb }}$ tem-se dançado muito por cá?

(PE - O festim de Baltazar, Gervásio Lobato, 1894)

b. Pois se $\varnothing_{\text {arb }}$ o fizerem deputado, é capaz de vender a pátria como vendia a justiça.

(PE - A liberdade eleitoral, Teixeira de Vasconcellos, 1870)

Tabela 1 - Distribuição das estratégias de indeterminação de referência "arbitrária" no PE ao longo do tempo

\begin{tabular}{|c|c|c|c|}
\hline PERÍODO & se & $\mathbf{3}^{\text {a }}$ p.p. & TOTAL \\
\hline Período I & $\begin{array}{c}35 \\
(49 \%)\end{array}$ & $\begin{array}{c}37 \\
(51 \%)\end{array}$ & $\begin{array}{c}72 \\
(100 \%)\end{array}$ \\
\hline Período II & $\begin{array}{c}40 \\
(61,5 \%)\end{array}$ & $\begin{array}{c}25 \\
(38,5 \%)\end{array}$ & $\begin{array}{c}65 \\
(100 \%)\end{array}$ \\
\hline Período III & 15 & 43 & 58 \\
& $(26 \%)$ & $(74 \%)$ & $(100 \%)$ \\
\hline Período IV & 16 & 18 & 34 \\
& $(47 \%)$ & $(53 \%)$ & $(100 \%)$ \\
\hline Período V & 13 & 21 & 34 \\
& $(38 \%)$ & $(62 \%)$ & $(100 \%)$ \\
\hline Período VI & 18 & 34 & 52 \\
& $(35 \%)$ & $(65 \%)$ & $(100 \%)$ \\
\hline Período VII & 6 & 34 & 40 \\
& $(15 \%)$ & $(85 \%)$ & $(100 \%)$ \\
\hline TOTAL & 143 & 212 & 355 \\
\hline \multicolumn{2}{|r|}{ Fonte: Adaptada de Cardoso (2017, p. 66). } \\
\hline
\end{tabular}

Lembramos que aqui, a $3^{\text {a }}$ pessoa do plural pode ter o pronome "eles" nulo ou expresso, sendo a representação nula a que predomina no PE. Uma leitura da tabela 1 nos diz que no PE, a indeterminação de caráter arbitrário (caracterizada pelos traços $[+3 \mathrm{p} /+\mathrm{pl}]$, que exclui o falante, abrangendo um conjunto finito de entidades), embora com presença consistente do clítico "se", prefere a $3^{\text {a }}$ pessoa do plural, com exceção do período II.

No PB, ilustramos as estratégias que veiculam a referência "arbitrária" no PB antes dos resultados na Tabela 2.

(20) a. Tomara que já $\varnothing_{\text {gen }}$ se organize o ministério, só para assim ver se teu pai sossega.

(PB - Como se fazia um deputado, França Júnior, 1882) 
b. Oh, por lá é que se recompensa o verdadeiro mérito! Aqui $\varnothing_{\text {arb julgam que }}$ $\varnothing_{\text {arb }}$ fazem tudo pagando com dinheiro.

(PB - Quem casa, quer casa, Martins Pena, 1845)

Tabela 2 - Distribuição das estratégias de indeterminação de referência "arbitrária" no $\mathrm{PB}$ ao longo do tempo

\begin{tabular}{|c|c|c|c|}
\hline PERÍODO & se & $\mathbf{3}^{\text {a }}$ p.p. & TOTAL \\
\hline Período I & $\begin{array}{c}18 \\
(22 \%)\end{array}$ & $\begin{array}{c}74 \\
(78 \%)\end{array}$ & $\begin{array}{c}92 \\
(100 \%)\end{array}$ \\
\hline Período II & $\begin{array}{c}19 \\
(27 \%)\end{array}$ & $\begin{array}{c}52 \\
(73 \%)\end{array}$ & $\begin{array}{c}71 \\
(100 \%)\end{array}$ \\
\hline Período III & 13 & 47 & 60 \\
$(22 \%)$ & $(78 \%)$ & $(100 \%)$ \\
\hline Período IV & 12 & 38 & 50 \\
$(24 \%)$ & $(76 \%)$ & $(100 \%)$ \\
\hline Período V & 6 & 51 & 57 \\
& $(11 \%)$ & 31 & $(100 \%)$ \\
\hline Período VI & 2 & $(94 \%)$ & $(100 \%)$ \\
\hline Período VII & $(6 \%)$ & 38 & 38 \\
& --- & $(100 \%)$ & $(100 \%)$ \\
\hline TOTAL & 70 & 331 & 401 \\
\hline
\end{tabular}

Fonte: Adaptada de Cardoso (2017, p. 82).

Quanto ao PB, a $3^{\text {a }}$ pessoa do plural (que, ao longo do tempo vai preferindo o pronome expresso ao nulo), sempre foi superior ao uso do clítico "se", que ocorre em torno de $20 \%$ até o período IV (anos 1930), começa a mostrar uso reduzido a partir de então, até seu desaparecimento na última sincronia representada nesta amostra, confirmando os resultados de Marins, Soares da Silva e Duarte (2017), que reanalisam a amostra de fala carioca recolhida no mesmo período da escrita das peças da última sincronia (anos 1990), quando seu uso se mostra extinto na fala das gerações mais jovens, com ocorrências muito raras na fala dos letrados mais velhos.

Passemos aos resultados para a expressão da indeterminação que veicula referência genérica, reunindo aqui os sujeitos que incluem um conjunto infinito de seres, podendo o falante estar ou não entre eles. Como se poderá ver nas tabelas que seguem, o PE se limita a três estratégias: o clítico, a $1^{\text {a }}$ p.p. (com o pronome "nós" geralmente nulo) e "a gente", ainda não plenamente gramaticalizado nessa variedade, como mostram Lopes e Brocardo (2016). Exemplos do PE em (21) precedem a Tabela 3.

(21) a. Outra mais importante te quero eu fazer. Dize-me, nesta casa $\varnothing_{\text {gen }}$ não se janta?

(PE - Uma cena de nossos dias, Paulo Midosi, 1843) 
b. Toda a gente, agora, morre do coração. Também não admira, com esta vida que $\varnothing_{\text {gen }}$ levamos, sempre a correr dum lado para o outro, numa estafadeira, com mil preocupações dentro da cabeça...

(PE - Alguém terá que morrer, Luiz Francisco Rebello, 1954)

c. Quando a gente ${ }_{i}$ quer, mas $\varnothing_{\text {gen i }}$ quer cá de dentro, com força, $\varnothing_{\text {gen i }}$ quer mesmo - não há nada que seja impossível... E se tu quisesses...

(PE - É urgente o amor, Luiz Francisco Rebello, 1957)

Tabela 3 - Distribuição das estratégias de indeterminação com referência "genérica" no PE ao longo do tempo

\begin{tabular}{|c|c|c|c|c|}
\hline PERÍODO & se & $\mathbf{1}^{\text {a }}$ p.p. & a gente & TOTAL \\
\hline Período I & $\begin{array}{c}44 \\
(94 \%)\end{array}$ & $\begin{array}{c}3 \\
(6 \%)\end{array}$ & $\begin{array}{c}--- \\
47 \\
(100 \%)\end{array}$ \\
\hline Período II & $\begin{array}{c}56 \\
(93 \%)\end{array}$ & $\begin{array}{c}3 \\
(5 \%)\end{array}$ & $\begin{array}{c}1 \\
(2 \%)\end{array}$ & $\begin{array}{c}60 \\
(100 \%)\end{array}$ \\
\hline Período III & 39 & 3 & 0 & 42 \\
& $(93 \%)$ & $(7 \%)$ & --- & $(100 \%)$ \\
\hline Período IV & 54 & 3 & 0 & 57 \\
& $(95 \%)$ & $(5 \%)$ & --- & $(100 \%)$ \\
\hline Período V & 93 & 9 & 21 & 123 \\
& $(76 \%)$ & $(7 \%)$ & $(17 \%)$ & $(100 \%)$ \\
\hline Período VI & 68 & 4 & 3 & 75 \\
& $(91 \%)$ & $(5 \%)$ & $(4 \%)$ & $(100 \%)$ \\
\hline Período VII & 51 & 20 & 7 & 78 \\
& $(65 \%)$ & $(26 \%)$ & $(9 \%)$ & $(100 \%)$ \\
\hline TOTAL & 405 & 45 & 32 & 482 \\
\hline
\end{tabular}

Observando a Tabela 3, vemos que o pronome "se" é o detentor absoluto da preferência para veicular a referência genérica no PE. O uso da $1^{\text {a }}$ pessoa do plural, que inclui o falante, e, no PE, vem geralmente com o pronome nulo, é muito tímido, só alcançando percentual significativo (26\%) na última sincronia. O uso de "a gente" tem distribuição irregular, apresentando índices mais significativos no período V (anos 1950-1960).

Quanto ao PB, com alguns exemplos em (22), vemos na Tabela 4, um cenário completamente diferente.

(22) a. E se $\varnothing_{\text {arb }}$ se formar um terceiro partido? Sim porque devemos prevenir todas as hipóteses.

(PB - Como se fazia um deputado, França Júnior, 1882) 
b. Mamãe, tudo se faz. $\varnothing_{\text {gen }}$ Não podemos ficar muito presos a uma moral só. $\varnothing_{\text {gen }}$ Temos que experimentar várias!

(PB - Um elefante no caos, Millôr Fernandes, 1955)

c. Ah, minha amiga, a gente não pode ficar com muito luxo $\varnothing_{\text {gen }}$ quando quer viver bem assim, não. Isto só se tem com tutano nos ossos e revólver na cinta.

(PB - Pedro Mico, Antonio Callado, 1954)

d. Se você come produtos extraídos da vaca, $\varnothing_{\text {gen }}$ vai ficando com uma mentalidade bovina.

(PB - Confidências de um espermatozoide careca, Carlos Eduardo Novaes, 1984)

e. - Me prometeram um lugar de atendente de dentista em Olaria. $\varnothing_{\text {gen }}$ Tem que aprender a mexer com aqueles ferrinhos, mas o salário parece que compensa.

(PB - No Coração do Brasil, Miguel Falabella)

Tabela 4 - Distribuição das estratégias de indeterminação genérica no PB ao longo do tempo

\begin{tabular}{|c|c|c|c|c|c|}
\hline PERÍODO & $\mathbf{s e}_{\text {gen }}$ & $\mathbf{1}^{\text {a }}$ p.p. & a gente & você & TOTAL \\
\hline Período I & $\begin{array}{c}21 \\
(92 \%)\end{array}$ & $\begin{array}{c}1 \\
(4 \%)\end{array}$ & $\begin{array}{c}1 \\
(4 \%)\end{array}$ & --- & $\begin{array}{c}23 \\
(100 \%)\end{array}$ \\
\hline Período II & $\begin{array}{c}55 \\
(87 \%)\end{array}$ & $\begin{array}{c}3 \\
(5 \%)\end{array}$ & $\begin{array}{c}5 \\
(8 \%)\end{array}$ & --- & $\begin{array}{c}63 \\
(100 \%)\end{array}$ \\
\hline Período III & 58 & 5 & 16 & --- & 79 \\
& $(74 \%)$ & $(6 \%)$ & $(20 \%)$ & & $(100 \%)$ \\
\hline Período IV & 69 & 3 & 8 & --- & 80 \\
& $(86 \%)$ & $(4 \%)$ & $(10 \%)$ & & $(100 \%)$ \\
\hline Período V & 35 & 4 & 16 & --- & 55 \\
& $(64 \%)$ & $(7 \%)$ & $(29 \%)$ & & $60 \%)$ \\
\hline Período VI & 3 & 12 & 21 & 24 & $(100 \%)$ \\
\hline Período VII & $(5 \%)$ & $(20 \%)$ & $(35 \%)$ & $(40 \%)$ & 79 \\
& $(6 \%)$ & $(1 \%)$ & $(65 \%)$ & $(28 \%)$ & $(100 \%)$ \\
\hline TOTAL & 246 & 29 & 118 & 46 & 401 \\
\hline
\end{tabular}

Fonte: Adaptada de Cardoso (2017, p. 82).

A Tabela 4 revela que o uso de "se" para veicular a referência genérica predomina até o período V (anos 1950), quando cai abruptamente na segunda metade do século XX, chegando a 3 e 5 ocorrências, respectivamente, nos períodos VI e VII. O uso de "a gente" se sobrepõe a "nós", e se fortalece bem antes do que mostram os resultados do PE, chegando a ser a estratégia mais frequente na amostra. O mais interessante nos resultados é o aparecimento de "você" na segunda metade do século $\mathrm{XX}$, hoje a estratégia mais frequente para veicular esse tipo de referência (tendo como variante o 
pronome "tu" nas regiões em que este é o pronome de $2^{a}$ pessoa). Esses resultados para "você" e "a gente" confirmam o que Lopes e Brocardo (2016) dizem acerca da gramaticalização (pronominalização) mais rápida de ambos os pronomes no português brasileiro do que no europeu, tanto para expressar referência definida quanto genérica. Confirma essa hipótese o uso de "a gente" como SN antecedido de um quantificador (21b) nos exemplos do PE. O único dado com o nulo genérico é ilustrado em (22e) acima.

Uma última observação sobre as formas pronominais nominativas para expressar a indeterminação (arbitrária e genérica) é a sua expressão nula ou plena. O gráfico 5 compara os resultados para as formas pronominais - (eles), (nós), (a gente) e (você), considerando os dados reanalisados de Vargas $(2010,2012)$ para as peças do PB e os de Cardoso para as do PE:

Gráfico 5 - Formas pronominais nulas (x expressas) no PB e no PE

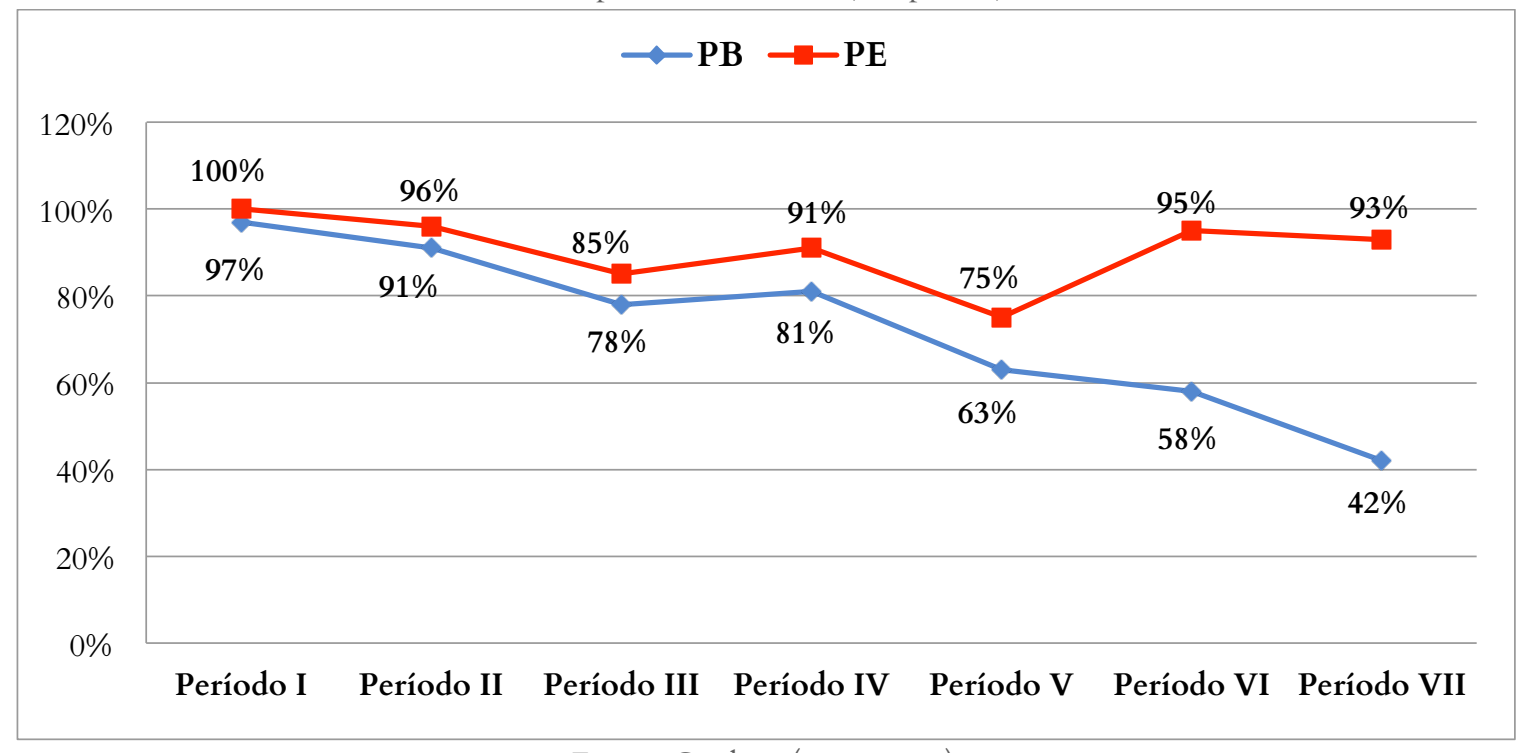

Fonte: Cardoso (2017, p. 91)

Como esperado num sistema de sujeitos nulos “consistente" (ROBERTS; HOLMBERG, 2010), o PE se mostra bastante estável quanto ao uso das formas pronominais nulas, começando com 100\% de ocorrências e apresentando apenas uma pequena variação ao longo dos períodos, mas sempre com índices muito altos. Esse tipo de comportamento é o que se vê no PE no que se refere aos sujeitos referenciais definidos. O PB apresenta o mesmo comportamento do PE até o período IV (anos 1930), tal como vimos em relação aos clíticos, mas, a partir do período V (anos 1950), começamos a observar o início de uma curva descendente de pronomes nulos em favor da representação por pronomes expressos, acompanhando a mudança atestada nos sujeitos referenciais definidos (DUARTE, 2018, 2019), uma mudança "encaixada" no sistema linguístico, de acordo com nosso referencial teórico, 
com os sujeitos indeterminados acompanhando a mudança observada na representação dos sujeitos de referência definida (cf CYRINO; DUARTE; KATO, 2000).

\section{Juntando as três análises para concluir}

Voltando nossa atenção para o uso dos três clíticos, objeto principal deste artigo, podemos reunir seu percurso no $\mathrm{PE}$ e no $\mathrm{PB}$, reunindo em cada um dos três gráficos que seguem, o clítico acusativo, o dativo e o indefinido (arbitrário e genérico) versus suas formas variantes em conjunto, ilustradas nas seções precedentes, excetuando o nulo arbitrário, que não aparece nas amostras e o nulo genérico, com apenas uma ocorrência no PB. A comparação entre as duas variedades é eloquente.

Gráfico 6 - Clítico acusativo de $3^{a}$ pessoa (vs. formas variantes) no PE e no PB

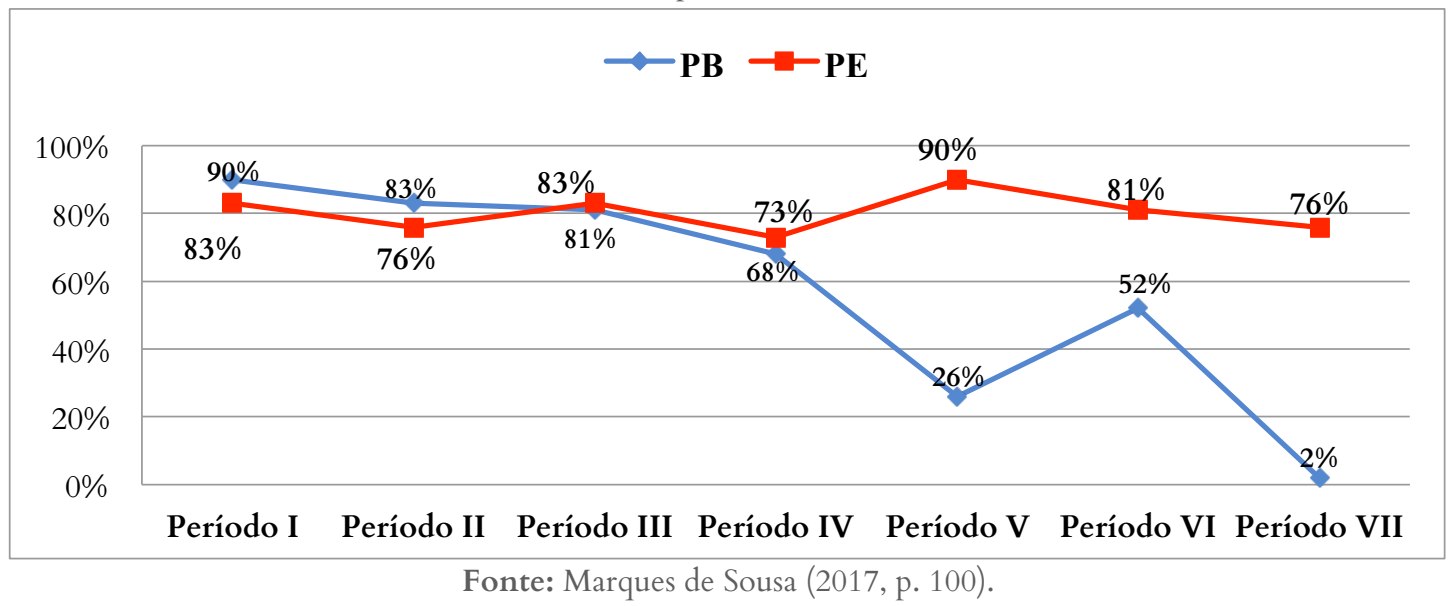

Gráfico 7 - Clítico dativo de $3^{\text {a }}$ pessoa (vs. formas variantes) no PE e no PB

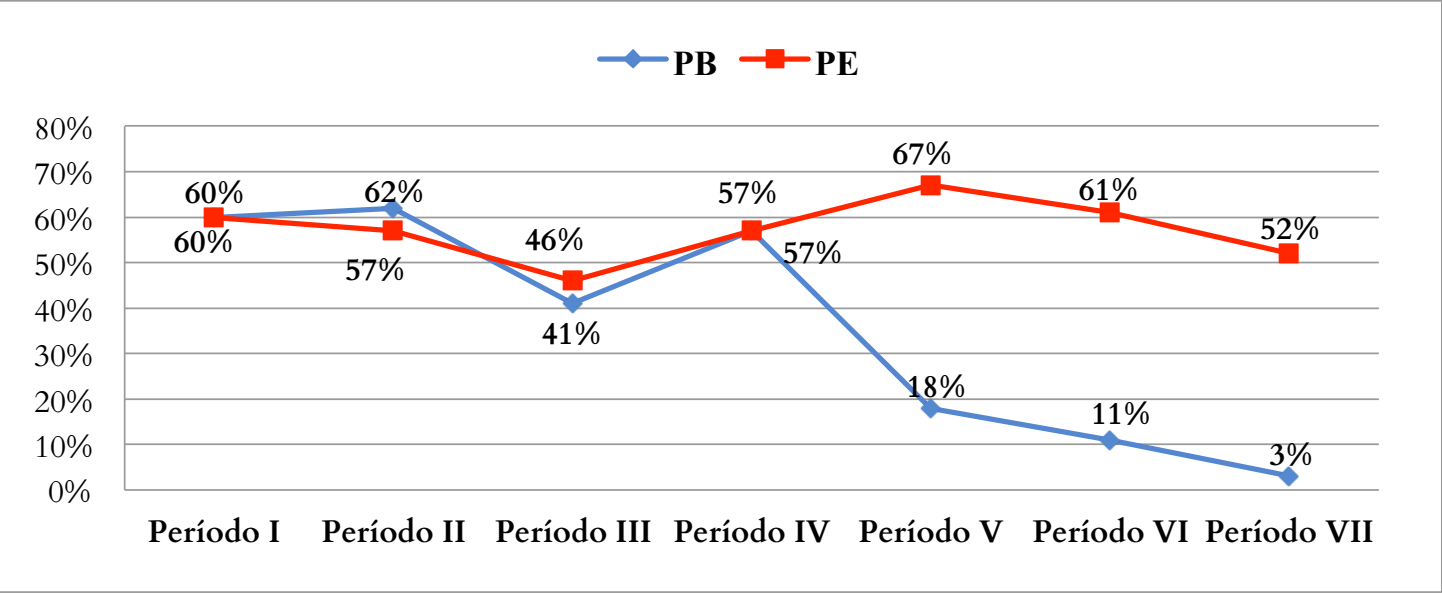

Fonte: Fernandes (2018, p. 78). 
Gráfico 8 - Clítico indefinido (arbitrário e genérico) (vs. formas variantes) no PE e no PB

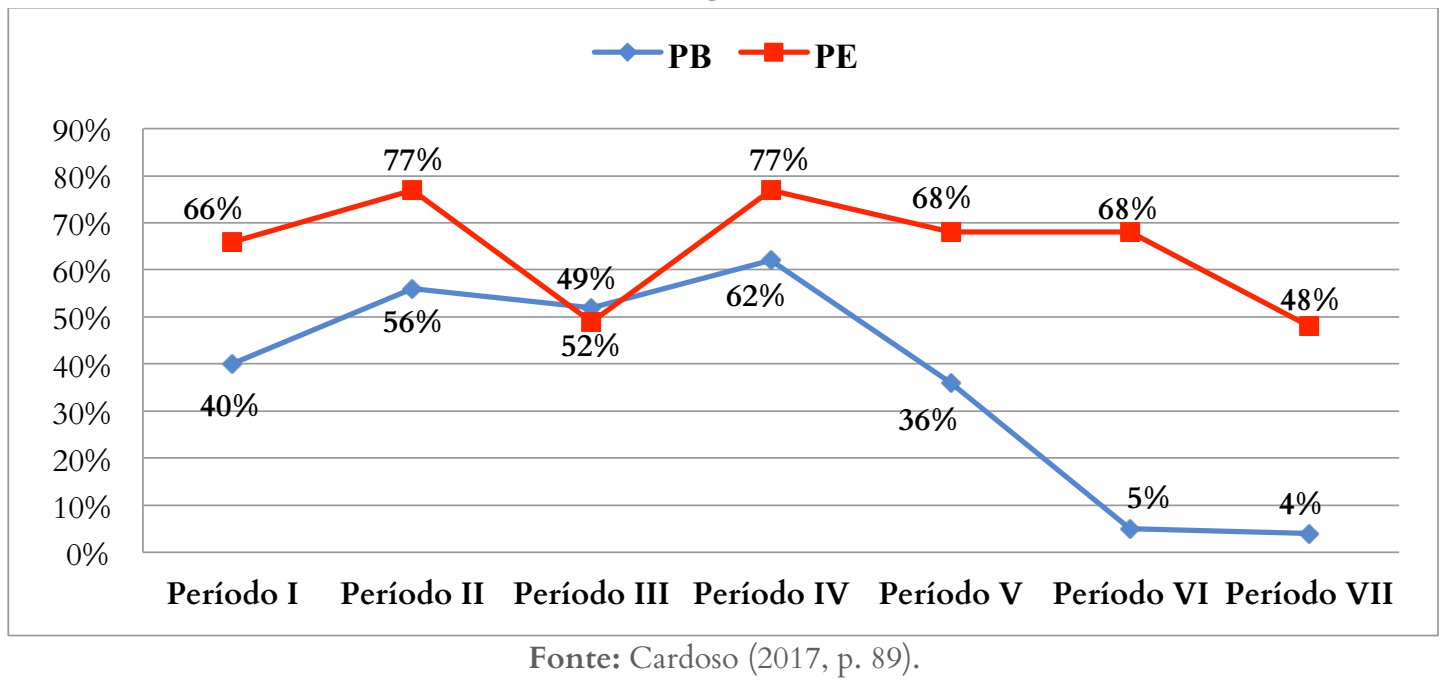

Ao compararmos PE e PB, fica claro que estamos diante de variedades distintas. Enquanto no $\mathrm{PE}$, a linha vermelha revela um sistema robusto de clíticos ao longo dos sete períodos, observamos no $\mathrm{PB}$, por outro lado, uma vertiginosa curva descendente a partir do Período IV, que corresponde aos anos 1930-1940, consolidando-se no Período V (anos 1950-1960), quando os autores brasileiros deixam de tentar reproduzir a norma lusitana.

Podemos, com base nos percentuais, atestar a obsolescência dos clíticos de terceira pessoa acusativo e dativo - e do clítico indefinido, confirmando nossa hipótese inicial de que seu comportamento diferencia os clíticos de $1^{\mathrm{a}}$ e $2^{\mathrm{a}}$ pessoas, dêiticos, que se comportam como sintagmas como defende Galves (2019). Comportamento diferente exibem o clítico acusativo, o dativo e o indefinido (esses dois incluídos por nós), que são elementos de concordância e, como propõe Galves (2019), estão inseridos "num quadro mais amplo de perda de morfologia associada à aquisição do português no Brasil como segunda língua” (p. 129).

Essa redução drástica, que nos leva a 2\%,3\% e 4\% desses três clíticos, além do enfraquecimento da morfologia, reforça a hipótese de que complementos nulos são recuperados pela orientação para o discurso, que permite ao $\mathrm{PB}$ identificar uma categoria vazia vinculada a um tópico proeminente no contexto precedente ou no contexto pragmático. Por outro lado, o que sustenta o desaparecimento do clítico indefinido, que não conta com um referente no contexto discursivo, é sua substituição motivada por uma morfologia verbal enfraquecida, substituído por um sistema de pronomes fracos (KATO, 1990), que passam a ocupar o especificador de TP, a posição estrutural do sujeito. Daí o uso cada vez mais frequente de pronomes nominativos e a remarcação do valor do Parâmetro do Sujeito Nulo no PB (DUARTE, 1993, 1995, 2019). Fechamos este artigo com as palavras da homenageada neste número sobre o renascimento dos estudos histórico-diacrônicos: 
Depois do recesso historicista, decorrente da hegemonia do sincrônico contemporâneo na linguística brasileira das décadas de 60 e 70, ressurgiu a Fênix nos anos 80. Tenho usado algumas vezes essa metáfora de Fernando Tarallo, cuja menção neste momento já é uma homenagem ao instigante filão que abriu para a compreensão do português brasileiro na perspectiva da sintaxe diacrônica. (MATTOS E SILVA, R. V., 1998, p. 22) 


\section{Referências bibliográficas}

BIBERAUER, T. et al. (eds.) Parametric Variation: null subjects in Minimalist theory. Cambridge: Cambridge University Press, 2010.

CARDOSO, M. M. C. Estratégias de Indeterminação em Peças Portuguesas e Brasileiras: uma análise contrastiva. Dissertação de Mestrado, UFRJ. 2017.

COSTA, S. O (não) preenchimento do objeto anafórico na Língua Portuguesa: análise diacrônica do PB e do PE dos séculos XIX e XX. Tese de Doutorado, UFSC, 2011.

CYRINO, S. O ON no português do Brasil - um estudo sintático-diacrônico. Tese de Doutorado, Unicamp, 1994.

CYRINO, S. O ON no português do Brasil - um estudo sintático-diacrônico. Londrina: Editora UEL, 1997.

CYRINO, S. O objeto nulo do português brasileiro: sincronia e diacronia. In: GALVES, C.; KATO, M. A.; ROBERTS, I. (org). Português brasileiro: uma segunda viagem diacrônica. São Paulo: Editora Unicamp, 2019. p. 173-199.

CYRINO, S. M. L.; DUARTE, M. E. L.; KATO; M. A. Visible subjects and invisible clitics in Brazilian Portuguese. In: KATO, M. A; NEGRÃO, E. V. (Orgs.). Brazilian Portuguese and the Null Subject Parameter. $1^{\circ}$ ed. Frankfurt am Maim/Madrid: Vervuert/Iberoamericana, 2000. p. 55-73.

CYRINO, S.; MATOS, G. Null Objects and VP Ellipsis in European and Brazilian Portuguese. In: WETZELS, L.; MENUZZI, S; COSTA, J. (eds.) The Handbook of Portuguese Linguistics. Malden: Wiley Blackwell. 2016. p. 294-317

DUARTE, I.; COSTA, J. Objeto Nulo. In: RAPOSO E.; et al. (orgs). Gramática do Português, vol. II. Lisboa: Fundação Calouste Gulbenkian, 2013. p. 2339-2348

DUARTE, M. E. L. Variação e sintaxe: clítico acusativo, pronome lexical e categoria vazia no português do Brasil. Dissertação de mestrado, PUC-SP, 1986.

DUARTE, M. E. L. Clítico acusativo, pronome lexical e categoria vazia no português do Brasil. In: TARALLO, F. (org.) Fotografias Sociolinguísticas. Campinas: Pontes, 1989. p. 19-34.

DUARTE, M. E. L. Do pronome nulo ao pronome pleno; a trajetória do sujeito no português do Brasil. In: ROBERTS, I; KATO, M. A. (orgs.). Português brasileiro: uma viagem diacrônica homenagem a Fernando Tarallo. Campinas: Ed. da Unicamp, 1993. p. 107-128. Reeditado pela Editora Contexto em 2018.

DUARTE, M. E. L A perda do princípio "Evite Pronome" no português brasileiro. Tese de Doutorado em Linguística, UNICAMP, Campinas, 1995. 
DUARTE, M. E. L.; RAMOS, J. Variação nas funções acusativa, dativa e reflexiva. In: MARTINS, M. A.; ABRAÇADO J. (orgs.) Mapeamento sociolinguístico do português brasileiro. São Paulo: Contexto, 2015. p. 173-195.

DUARTE, M. E. L; FERNANDES, U. Construções de tópico-sujeito em contexto de variação e mudança. Web-Revista Sociodialeto, v. 6, p. 347-371, 2016.

DUARTE, M. E. L; MARINS, J. Brazilian Portuguese: a 'partial' null subject language?, Cadernos de Estudos Linguísticos, Unicamp, (a sair).

EGERLAND, V. Impersonal pronouns in Scandinavian and Romance. Working Papers in Scandinavian Syntax 71, p. 75-102, 2003.

FERNANDES, U. Realizações do dativo de $3^{\text {a }}$ pessoa em peças brasileiras e portuguesas: uma análise diacrônica. Dissertação de Mestrado, UFRJ, 2018.

FREIRE, G. C. Os clíticos de terceira pessoa e as estratégias para a sua substituição na fala culta brasileira e lusitana. Dissertação de Mestrado. Rio de Janeiro, UFRJ, 2000.

FREIRE, G. C. A realização do acusativo e dativo anafóricos na escrita brasileira e lusitana. Tese de Doutorado, UFRJ, 2005.

GALVES, C A Sintaxe do Português Brasileiro. Ensaios de Linguística, UFMG, n. 13, p. 31-50, 1987.

GALVES, C. O enfraquecimento da concordância no português brasileiro. In: ROBERTS, I; KATO, M. A. (orgs.). Português brasileiro: uma viagem diacrônica - homenagem a Fernando Tarallo. Campinas: Ed. da Unicamp, 1993. p. 343-386. Reeditado pela Editora Contexto em 2018.

GALVES, C. Revisitando a concordância no português brasileiro. In: GAKLVES, C; KATO, M. A.; ROBERTS, I. Português Brasileiro: uma segunda viagem diacrônica. São Paulo: Ed. da Unicamp, 2019. p. 127-150

GOMES, C. A Variação e mudança na expressão do dativo no português brasileiro. In: PAIVA, M. C; DUARTE, M. E. L. (orgs.). Mudança lingüística em tempo real. Rio de Janeiro, Contra Capa Livraria, 2003. p. 81-96.

GOMES, C. A. Uso variável do dativo na escrita jornalística: resistência e inovação na escrita formal contemporânea. In: Dinâmica da variação e da mudança na fala e na escrita. PAIVA, M. C.; Gomes, C. (orgs.) Rio de Janeiro, Contra Capa Livraria, 2014, p. 103-114.

KATO, M. A. Strong and weak pronouns in the null subject parameter. PROBUS, v. 11, n. 1, p. 11-38, 1999.

LOPES, C.; PROCARDO, M. T. Main Morphosyntactic changes and Grammaticalization Processes. In: WETZELS, L.; MENUZZI, S; COSTA, J. (eds.) The Handbook of Portuguese Linguistics. Malden: Wiley Blackwell. 2016. p. 471-486. 
LUNGUINHO, M. V.; MEDEIROS JR. P. Inventou um novo tipo de sujeito: características sintáticas e semânticas de uma estratégia de indeterminação do sujeito no português brasileiro. Revista de Estudos em Língua e Literatura, v. 23, p. 147-191, 2009.

MARQUES DE SOUSA, A. A. As realizações do acusativo anafórico no português europeu e brasileiro: um estudo diacrônico. Dissertação de Mestrado em Letras Vernáculas - Língua Portuguesa. Rio de janeiro. Universidade Federal do Rio de Janeiro, 2017.

MARTINS, A. M.; NUNES, J. Passives and se Constructions. In: WETZELS, L.; MENUZZI, S; COSTA, J. (eds.) The Handbook of Portuguese Linguistics. Malden: Wiley Blackwell. 2016. p. 318-337.

MATTOS E SILVA, R. V. Idéias para a história do português brasileiro: fragmentos para uma composição posterior. In: CASTILHO, A. de. (org,) Para a História do Português Brasileiro: primeiras idéias. São Paulo: Humanitas, 1998. p. 21-52.

NUNES, J. Direção de cliticização, objeto nulo e pronome tônico na posição de objeto em português brasileiro. In: ROBERTS, I; KATO, M. A. (orgs). Português brasileiro: uma viagem diacrônica - homenagem a Fernando Tarallo. Campinas: Ed. da Unicamp, 1993. p. 207-222. Reeditado pela Editora Contexto em 2018.

NUNES, J. Clíticos acusativos de terceira pessoa em português brasileiro como concordância de objeto. In: GALVES, C.; KATO, M. A.; ROBERTS, I. (orgs). Português brasileiro: uma segunda viagem diacrônica. São Paulo: Editora Unicamp, 2019. p. 151-172.

ROBERTS, I; HOLMBERG, A. Introduction: parameters in Minimalist theory. In: BIBERAUER, T.; et al. (eds). Parametric Variation: null subjects in Minimalist theory. Cambridge: Cambridge University Press. 2010. p. 1-57.

SANKOFF, D.; TAGLIAMONTE, S; SMITH. E. Goldvarb X: A variable rule application for Macintosh and Windows. Department of Linguistics, University of Toronto. 2005. Available for download from: http://individual.utoronto.ca/tagliamonte/goldvarb.html.

VARGAS, A. Estratégias pronominais de indeterminação: um estudo diacrônico. Dissertação de Mestrado, UFRJ, 2010.

VARGAS, A. A evolução na representação das estratégias pronominais de indeterminação. In: DUARTE, M. E. L. (Org.). O sujeito em peças de teatro (1833-1892): estudos diacrônicos. São Paulo: Parábola, 2012. p. 45-67. 
Anexos

Anexo I - Distribuição das peças brasileiras por período de tempo

\begin{tabular}{|c|c|c|}
\hline Ano & Peça (ano de publicação ou de estreia) & $\begin{array}{l}\text { Autor (ano de nascimento - ano } \\
\text { de falecimento) }\end{array}$ \\
\hline Período I & $\begin{array}{l}\text { - Um sertanejo na corte (1837) } \\
\text { - O noviço (1845) } \\
\text { - As casadas solteiras (1845) } \\
\text { - Quem casa, quer casa (1845) } \\
\text { - O cigano (1845) } \\
\text { - O Judas em sábado de aleluia (1846) } \\
\text { - Os irmãos das Almas (1847) }\end{array}$ & Martins Pena (1815-1848) \\
\hline Período II & $\begin{array}{l}\text { - Tipos da atualidade (1862) } \\
\text { - Defeito de Família (1870) } \\
\text { - Como se fazia um deputado (1882) } \\
\text { - Caiu o ministério (1883) } \\
\text { - As doutoras (1889) }\end{array}$ & França Júnior (1820-1882) \\
\hline Período III & $\begin{array}{l}\text { - O simpático Jeremias (1918) } \\
\text { - As "fans" de Roberto Taylor (1919) } \\
\text { - Onde canta o sabiá (1920) } \\
\text { - A Inquilina de Botafogo (1920) }\end{array}$ & Gastão Tojeiro (1880-1965) \\
\hline Período IV & $\begin{array}{l}\text { - O Troféu (1933) } \\
\text { - A Patroa (1933) } \\
\text { - O hóspede do quarto no } 2 \text { (1937) } \\
\text { - A vida tem três andares (1938) }\end{array}$ & Humberto Cunha (1887-1966) \\
\hline Período V & $\begin{array}{l}\text { - Pedro Mico (1954) } \\
\text { - O colar de coral (1954) } \\
\text { - Um elefante no caos ou jornal do Brasil } \\
\text { ou, sobretudo, por que me ufano do meu } \\
\text { país (1955) } \\
\text { - A gaivota (1957) }\end{array}$ & $\begin{array}{l}\text { Antonio Callado (1917-1997) } \\
\text { Millôr Fernandes (1923-2012) }\end{array}$ \\
\hline Período VI & $\begin{array}{l}\text { - A mulher integral (1975) } \\
\text { - Confidências de um espermatozóide } \\
\text { careca (1984) } \\
\text { - Os órfãos de Jânio (1979) }\end{array}$ & 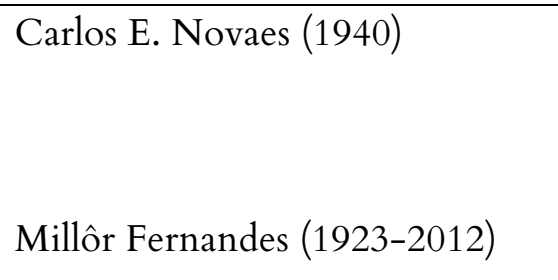 \\
\hline Período VII & $\begin{array}{l}\text { - A partilha (1990) } \\
\text { - No coração do Brasil (1992) } \\
\text { - Como encher um biquíni selvagem } \\
\text { (1992) }\end{array}$ & Miguel Falabella (1956) \\
\hline
\end{tabular}


Anexo II - Distribuição das peças portuguesas por período de tempo

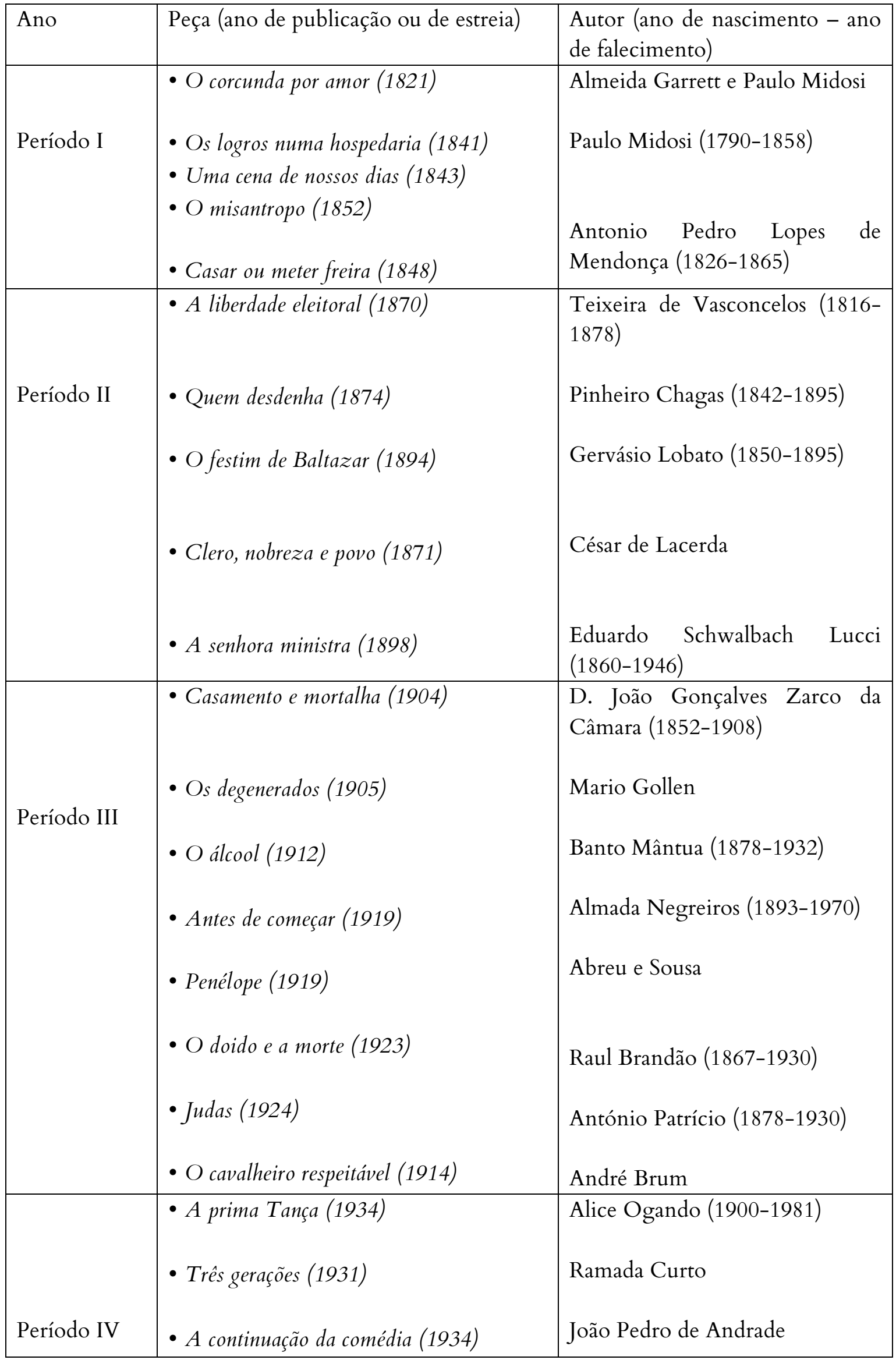




\begin{tabular}{|c|c|c|}
\hline & $\begin{array}{l}\text { - Balada de outono (1945) } \\
\text { - Meu amor é traiçoeiro (1935) } \\
\text { - O cúmplice (1940) } \\
\text { - A invenção do guarda-chuva (1944) }\end{array}$ & $\begin{array}{l}\text { (1902-1974) } \\
\text { Carlos Selvagem } \\
\text { Vasco de Mendonça Alves (1883) } \\
\text { Joaquim Paço D'arcos (1908- } \\
\text { 1979) } \\
\text { Luiz Francisco Rebello (1924- } \\
\text { 2011) }\end{array}$ \\
\hline Período V & $\begin{array}{l}\text { - Alguém terá que morrer (1954) } \\
\text { - É urgente o amor (1957) } \\
\text { - A sogra (1955) }\end{array}$ & $\begin{array}{l}\text { Luiz Francisco Rebello } \\
(1924-2011) \\
\text { Alice Orgando }\end{array}$ \\
\hline Período VI & $\begin{array}{l}\text { - A visita de sua excelência (1962-65) } \\
\text { - Prólogo Alentejano (1975) } \\
\text { - A lei é lei (1977) } \\
\text { - O grande mágico (1979) } \\
\text { - A menina feia (1970) } \\
\text { - O rosto levantado (1977) } \\
\text { - Viagem a Damasco (1980) } \\
\text { - Magalona, princesa de Nápoles (1986) }\end{array}$ & $\begin{array}{l}\text { Luis Francisco Rebello (1924- } \\
\text { 2011) } \\
\text { Manuel Frederico Pressler } \\
\text { Noberto Ávila (1936) }\end{array}$ \\
\hline Período VII & $\begin{array}{l}\text { - A vingança de Antero ou a boda } \\
\text { deslumbrante (1995) } \\
\text { - Um filho (1996) }\end{array}$ & Luísa Costa Gomes (1957) \\
\hline
\end{tabular}

